\title{
The Therapeutic Potential for PI3K Inhibitors in Autoimmune Rheumatic Diseases
}

\author{
Edward Banham-Hall ${ }^{1}$, Menna R. Clatworthy ${ }^{2}$ and Klaus Okkenhaug ${ }^{*}, 1$ \\ ${ }^{1}$ Laboratory of Lymphocyte Signalling and Development, The Babraham Institute, Babraham Research Campus, CB22 \\ $3 A T, U K$ \\ ${ }^{2}$ Cambridge Institute for Medical Research and the Department of Medicine, University of Cambridge School of Clinical \\ Medicine, Cambridge CB2 OXY, UK
}

\begin{abstract}
The class 1 PI3Ks are lipid kinases with key roles in cell surface receptor-triggered signal transduction pathways. Two isoforms of the catalytic subunits, $\mathrm{p} 110 \gamma$ and $\mathrm{p} 110 \delta$, are enriched in leucocytes in which they promote activation, cellular growth, proliferation, differentiation and survival through the generation of the second messenger PIP ${ }_{3}$. Genetic inactivation or pharmaceutical inhibition of these PI3K isoforms in mice result in impaired immune responses and reduced susceptibility to autoimmune and inflammatory conditions. We review the PI3K signal transduction pathways and the effects of inhibition of $\mathrm{p} 110 \gamma$ and/or p $110 \delta$ on innate and adaptive immunity. Focusing on rheumatoid arthritis and systemic lupus erythematosus we discuss the preclinical evidence and prospects for small molecule inhibitors of p110 $\gamma$ and/or p1 $10 \delta$ in autoimmune disease.
\end{abstract}

Keywords: PI3K inhibitors, humoral immune, systemic lupus erythematosus, pleckstrin homology, autoimmunity, rheumatoid arthritis, PI3K.

\section{OVERVIEW}

The inflammatory response is a complex and highly regulated consequence of stimuli received from pathogens or damaged cells. Inflammation is triggered by bacterial derivatives (e.g. LPS or fMLP), molecules released from damaged cells (e.g. ATP) and chemical mediators (such as complement) which activate resident cells of the innate immune system to engulf pathogens and release proinflammatory cytokines to recruit leucocytes to the inflamed tissue. Subsequently, T and B lymphocytes participate in a targeted and specific response following presentation of pathogen-derived or disease associated antigens [1].

This powerful system is critical for defence against pathogens. The severe and often lethal phenotypes exhibited by patients with defects in immune cell function illustrate all too clearly the importance of immune system integrity. However this essential system has great potential to harm the host. Lymphocytes gain tolerance to host tissues through clonal deletion, anergy or via suppression by regulatory $\mathrm{T}$ cells. When these processes fail autoreactive lymphocytes can cause autoimmune and inflammatory conditions, often resulting in significant morbidity $[2,3]$.

The diverse roles served by PI3K in the innate and adaptive immune system offer hope that inhibition of this axis may provide new treatments for autoimmune conditions [4]. The ultimate goal must be to alleviate pathological inflammation while leaving resistance to infection intact. In

*Address correspondence to this author at the Laboratory of Lymphocyte Signalling and Development, The Babraham Institute, Babraham Research Campus, CB22 3AT, UK; Tel: (01223) 496000; Fax: (01223) 496002;

E-mail: klaus.okkenhaug@babraham.ac.uk this review we discuss the current understanding of class 1 PI3K signal transduction, with a particular focus on the PI3K isoforms $\mathrm{p} 110 \gamma$ and $\mathrm{p} 110 \delta$ which are enriched in leucocytes. We examine how targeting these isoforms shows promise as a therapeutic strategy in autoimmunity, focussing on two systemic rheumatic diseases, rheumatoid arthritis (RA) and systemic lupus erythematosus (SLE), but also allude to other immune-related conditions that may be treated using PI3K inhibitors.

\section{PHOSPHOINOSITIDE 3-KINASES}

Phosphoinositide 3-kinases (PI3Ks) are lipid kinases that phosphorylate the 3-hydroxyl position of the inositol ring of phosphatidylinositol (PI) substrates within the plasma membrane and intracellular compartments. These substrates comprise PI, phosphatidylinositol-4-phosphate (PIP) and phosphatidylinositol-4,5-bisphosphate (PI-4,5- $\left.\mathrm{P}_{2}\right)$. The phosphorylated effector products recruit and activate proteins expressing the lipid-binding Pleckstrin Homology (PH), phox homology and FYVE domains. PI3Ks control a wide variety of cellular processes, including migration, proliferation, differentiation and vesicular trafficking [5-7].

PI3Ks are classified according to their sequence homology and substrate specificity. Class I PI3Ks convert PI-4,5- $\mathrm{P}_{2}$ into PtdIns-3,4,5-triphosphate ( $\left.\mathrm{PIP}_{3}\right)$, class II $\mathrm{PI} 3 \mathrm{Ks}$ convert PI-4-P into PI-3,4-P 2 and PI into PI-3-P, while the class III PI3K converts PI into PI-3-P. Class I PI3Ks are the most extensively studied and form the principle focus of this review. The biological functions of Class II PI3Ks are less well understood; the single class III PI3K enzyme Vacuolar Protein Sorting 34 (VPS34) is involved in vesicular intracellular trafficking and autophagy (Table 1). 
Table 1. Catalytic and Regulatory Subunits of PI3Ks and their Lipid Substrates and Products

\begin{tabular}{|c|c|c|c|c|}
\hline Class 1A & $\begin{array}{l}\mathrm{p} 110 \alpha \\
\mathrm{p} 110 \beta \\
\mathrm{p} 110 \delta\end{array}$ & $\mathrm{p} 85 \alpha, \mathrm{p} 85 \beta, \mathrm{p} 55 \alpha, \mathrm{p} 55 \gamma, \mathrm{p} 50 \alpha$ & PI-4,5-P ${ }_{2}$ & $\mathrm{PIP}_{3}$ \\
\hline Class 1B & $\mathrm{p} 110 \gamma$ & p101, p84 & PI-4,5-P ${ }_{2}$ & $\mathrm{PIP}_{3}$ \\
\hline Class III & VPS34 & p150 & PI & PI-3-P \\
\hline
\end{tabular}

PI3Ks have diversified throughout evolution: yeast have only a class III PI3K enzyme, Caenorhabditis elegans and Drosophila melanogaster have single isoforms of each of the class I, II and III enzymes, while mice and humans have four class I isoforms, three class II isoforms and one class III PI3K [8].

The class $1 \mathrm{~A}$ PI3K enzymes are heterodimers comprised of a regulatory subunit (p85) and a catalytic subunit (p110). Five regulatory Src Homology 2 (SH2) domain containing subunits have been identified; p $85 \alpha, \mathrm{p} 50 \alpha$, andp $55 \alpha$, (from alternative transcripts encoded by the Pik3rl gene), p $85 \beta$ (encoded by Pik3r2), and p55 (encoded by Pik3r3). Each of these regulatory subunits associates with any one of three catalytic subunits, $\mathrm{p} 110 \alpha, \mathrm{p} 110 \beta$ and $\mathrm{p} 110 \delta$. Class $1 \mathrm{~A}$ PI3K regulatory subunits contain $\mathrm{SH} 2$ domains which enable recruitment to tyrosine phosphorylated proteins at the plasma membrane, thus receptor tyrosine kinases (RTKs) form their principle means of activation. The p110 $\gamma$ catalytic subunit associates with either $\mathrm{p} 101$ or $\mathrm{p} 87 / \mathrm{p} 84$ to form the class $1 \mathrm{~B}$ PI3K heterodimer which is generally activated by G-coupled protein receptors (GPCRs) [5-7].

$p 110 \alpha$ and $p 110 \beta$ are ubiquitously expressed whereas $\mathrm{p} 110 \gamma$ and $\mathrm{p} 110 \delta$ are enriched in leucocytes. p110 is also expressed in some neurons [9] and cancer cell lines [10], but has low expression in other tissues. p110 $\gamma$ is expressed in cardiac myocytes and plays important roles in cardiac physiology, both as a kinase and as an adapter regulating cAMP-mediated signalling cascades [11-14].

The preferential signalling through $\mathrm{p} 110 \gamma$ and $\mathrm{p} 110 \delta$ isoforms in leucocytes has prompted considerable pharmaceutical interest [4]. Targeted inhibition of these isoforms should provide immunotherapeutic benefit while minimising organ toxicity. Indeed, compounds inhibiting p110 are already being assessed in clinical trials for the treatment of haematological malignancies [15-18]. Pan-PI3K and $\mathrm{p} 110 \alpha$-selective inhibitors are being evaluated in clinical trials for cancer [19].

\section{ACTIVATION OF PI3KS BY TYROSINE KINASE AND/OR G PROTEIN COUPLED RECEPTORS}

PI3K $\mathrm{p} 110 \gamma$ and $\mathrm{p} 110 \delta$ signalling is initiated by different cell surface receptors in different cell types of the immune system, transmitting signals promoting growth, activation and differentiation. Key signalling cascades are initiated in neutrophils, macrophages, dendritic cells, T cells, B cells and mast cells (summarised in Fig. 1).

All four of the class 1 PI3K's have a Ras binding domain (RBD) in their catalytic subunit and the physiological role of Ras in PI3K activation has been elucidated by generating mice with mutations in the $\mathrm{p} 110 \alpha$ or $\mathrm{p} 110 \gamma$ RBDs. In $\mathrm{p} 110 \gamma$ signalling, Ras has been shown to contribute to normal neutrophil function [20] whereas mice with a mutation in the p110 $\alpha$ RBD show impaired lymphatic vessel development and reduced viability and resistance to Ras oncogeneinduced tumourigenesis [21]. The Ras-related protein TC21 contributes to basal activation of $\mathrm{p} 110 \delta$ in B cells and T cells and $\mathrm{TC} 21^{-/-}$mice show some similarities with $\mathrm{p} 110 \delta$ deficient mice [22].

The simple concept that class $1 \mathrm{~A}$ PI3Ks are activated by growth factor and cytokine RTKs and the class $1 \mathrm{~B}$ PI3K is activated by chemokine responsive GCPRs does not always hold true. For instance, it is becoming increasingly clear that GCPRs can activate a wider range of PI3K isoforms than initially thought. p110 can be activated by GPCRs in B cells [23] and in natural killer cells [24], and p110 $\beta$ can be activated by GPCRs in cells where p110 $\gamma$ is not highly expressed or when tyrosine kinase and GPCR signals merge $[25,26]$. Conversely, the $\mathrm{p} 84 / \mathrm{p} 110 \gamma$ heterodimer was shown to be activated by tyrosine-kinase linked receptors in macrophages by a Ras-dependent mechanism [27].

\section{NEGATIVE REGULATION OF CLASS 1 PI3K SIGNALLING}

The PI3K-Akt signalling axis has a profound influence on cellular functions, and must therefore be tightly regulated. Constitutive activation of class 1 PI3K signalling predisposes to autoimmunity and cancer, while inactivation of isoforms has varying effects ranging from embryonic lethality to immune deficiency, demonstrating the critical importance of maintaining physiological balance in this cellular cascade. The tight control of $\mathrm{PIP}_{3}$ levels within the plasma membrane is controlled by phosphatases including PTEN and SHIP which dephosphorylate $\mathrm{PIP}_{3}$ on the D3 and D5 positions, respectively. Deletion of SHIP and/or PTEN in lymphocytes leads to a variety of autoimmune syndromes and leukaemia [28-31]. Interestingly, drugs that activate SHIP may be used as anti-inflammatory drugs, presumably by inhibiting PI3K signalling in blood cells [32]. 

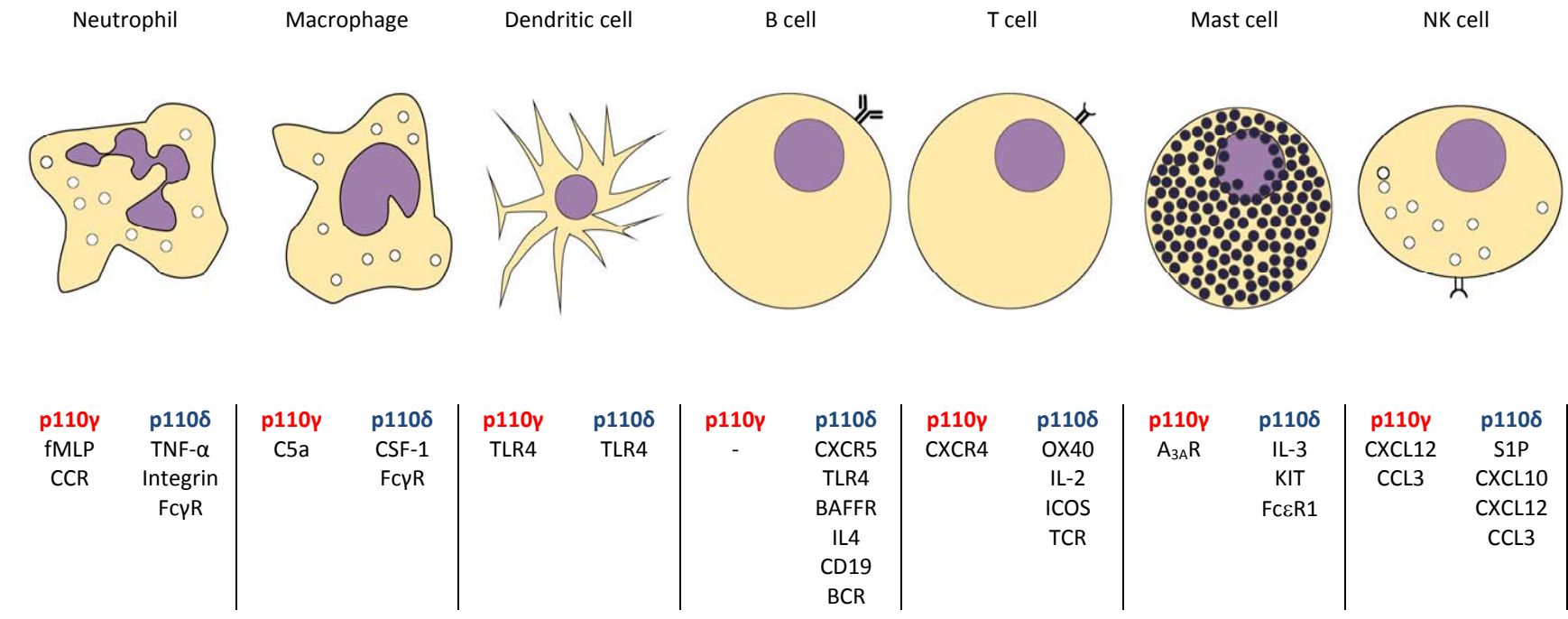

Fig. (1). p110 $\gamma$ and p110 $\delta$ are involved in the response to various cell signalling cascades that depend on cell type.

\section{DOWNSTREAM SIGNALLING}

The phosphorylation of PI-4,5- $\mathrm{P}_{2}$ to $\mathrm{PIP}_{3}$ at the inner leaflet of the cell membrane by PI3K permits the activation and recruitment of effector proteins expressing $\mathrm{PH}$ domains, including PDK1, Akt (also known as Protein Kinase B), guanine nucleotide exchange factors (GEF), and Tec family kinases. The best studied of these is the serine/threonine kinase Akt which can phosphorylate a large number of substrates [33]. Among these is the mammalian Target of Rapamycin mTOR [8] (Fig. 2). Rapamycin-based drugs are commonly used immunosuppressants in kidney transplant recipients [34]. Although rapamycin has been evaluated as a potential therapeutic in RA [35] and SLE [36], the associated adverse effects may be too severe for routine use in autoimmunity.

\section{Insights from Mouse Models}

The interrogation of signalling pathways in which the class I PI3Ks play a key role has been facilitated by the availability of small molecule inhibitors with high selectivity for the various class $1 \mathrm{~A}$ isoforms and the development of mice with inactivating mutations in PI3K genes. These strategies provided a considerable advance on earlier approaches which utilised wortmannin or LY294002 (panPI3K inhibitors with known off-target effects on class II and III PI3K's, mTOR and casein kinase 2) allowing the dissection of the contributions of specific PI3K isoforms to lymphocyte signalling, trafficking, proliferation and development.

Homozygous deletion of the gene for $\mathrm{p} 110 \alpha$ or $\mathrm{p} 110 \beta$ results in early embryonic lethality [37, 38]. Mice homozygous for an inactivating mutation in $\mathrm{p} 110 \alpha$ also die as embryos [39], whereas mice with an inactivating mutation of $\mathrm{p} 110 \beta$ are born at reduced Mendelian ratios, yet survive into adulthood indicating that an unexpected non-catalytic function of $\mathrm{p} 110 \beta$ partially protects against this mortality $[25,26,40]$.

By contrast mice with genetic inactivation of $\mathrm{p} 110 \gamma$ or p1 $10 \delta$ are born at normal Mendelian ratios and live a normal life span despite having impaired immune cell responses [41-
46]. The burgeoning interest in $\mathrm{p} 110 \gamma$ and $\mathrm{p} 110 \delta$ as therapeutic targets in autoimmunity has been built on substantial data emerging from the study of mice with genetic and pharmacological inactivation of these isoforms, examples of which are detailed in Table $\mathbf{2}$.

\section{PI3K IN B CELLS}

The key role for PI3K in B cell physiology was first demonstrated by $\mathrm{p} 85 \alpha^{-/ /}$mice which showed impaired B cell development and humoral immune responses [93, 94], and this phenotype was also seen in mice with p $110 \delta$ deletion or inactivation $[41,45,46]$. In particular, mice lacking $\mathrm{p} 85 \alpha$ or p110 have markedly reduced B1 cells (self-renewing IgM producing $\mathrm{B}$ cells populating the pleural and peritoneal cavities) and marginal zone B cells, with a lesser reduction in follicular B cells. In vivo, both the PI3K isoforms $\mathrm{p} 110 \alpha$ and $\mathrm{p} 110 \delta$ contribute to tonic survival signals generated by the $\mathrm{B}$ cell receptor (BCR) in absence of antigen, whereas p $110 \delta$ is preferentially activated by acute BCR signalling [75]. Reduced homing to Peyer's patches and splenic white pulp cords is seen in adoptively transferred kinase-dead $\mathrm{p} 110 \delta$ B cells, reflecting a role for $\mathrm{p} 110 \delta$ in B cell chemotaxis [23]. Mice lacking $\mathrm{p} 85 \alpha$ or $\mathrm{p} 110 \delta$ exhibit reduced T-independent antibody responses and $\mathrm{p} 110 \delta$ inactive $\mathrm{B}$ cells have reduced proliferative responses to antiIgM, anti-CD40 and interleukin(IL)-4 stimulation [41, 46, 67]. Furthermore, TLR9-mediated antibody class switching is blocked as a result of p110 inactivation [95]. However, p $110 \delta$ signalling also negatively regulates class switch recombination through activation-induced cytidine deaminase (AID) expression during germinal centre responses such that inhibiting $\mathrm{p} 110 \delta$ can increase class switching $[68,69,96]$.

Although much is known about the central role played by p110 in development and activity of conventional B cells, its precise function in the recently described regulatory B cell subset has not been reported. Regulatory B cells were first identified in mice and subsequently in humans, and mediate their regulatory function via the production of IL-10 [97-99], leading some authors to describe them as B10 cells [96]. In humans, IL-10 producers comprise $1-5 \%$ of 


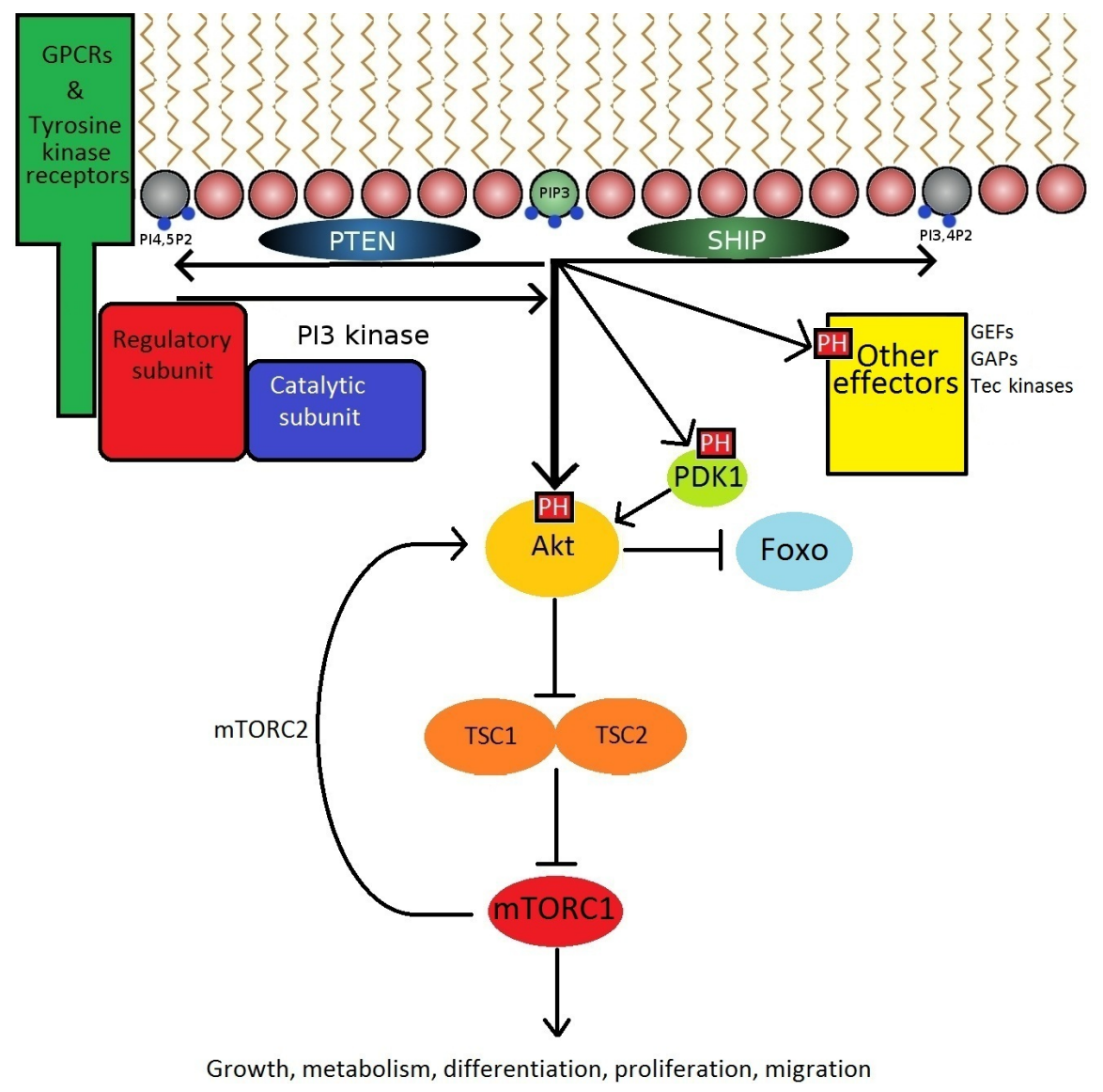

Fig. (2). The production of $\mathrm{PIP}_{3}$ is a critical signalling hub. GPCR's and receptor tyrosine kinases expressing a YxxM motif recruit PI3K to the plasma membrane via interactions with $\mathrm{SH} 2$ domains. PI3 kinases then catalyse the formation of $\mathrm{PIP}_{3}$ from PI-4,5- $\mathrm{P}_{2}$. PIP 3 then acts on a variety of downstream effectors expressing $\mathrm{PH}$ domains to promote cellular responses.

circulating B cells, although cells with the potential to produce IL-10 may be found at higher frequencies. Abnormalities in the number [95] or function [99] of regulatory $B$ cells have been described in patients with autoimmune diseases, suggesting that this subset may be of relevance to the development of treatments for autoimmunity.

Consistent with an important role for PI3K in B cell homeostasis, patients with $B$ cell malignancies have responded well to the $\mathrm{p} 110 \delta$-selective inhibitor CAL-101. In one study, all chronic lymphocytic leukaemia (CLL) patients treated with this inhibitor showed a reduction in lymph node size which was often associated with an increase in blood lymphoblast count [18]. However, patients who stopped taking the drug showed recurrent lymph node enlargement suggesting that the drug had not necessarily just killed the leukaemia cells - rather, these results raise the possibility that p $110 \delta$ is required for stromal cell support of proliferating CLL cells, perhaps by virtue of its role in chemokine receptor signalling. In vitro studies of the effect of CAL-101 on CLL cell viability showed that it was able to block the pro-survival effect of BCR cross-linking with IgM, as well as reducing elevated CCL3 and CCL4 levels [15, 100]. Further studies have shown that CAL-101 inhibits CLL cell chemotaxis and migration beneath stromal cells and sensitises CLL cells toward standard chemotherapeutic agents [101].

\section{PI3K IN T CELLS}

p1108-deficient mice have relatively normal numbers of thymocytes, while p110 $\gamma$-deficient mice have a modest reduction in numbers [43]. However, combined p110 / p110 $\delta$ deficiency has a much more significant impact on thymocyte numbers, with substantially reduced transition through the $\mathrm{CD}^{-} \mathrm{CD}^{-}$stage and reduced survival of cells at the $\mathrm{CD}^{+} \mathrm{CD}^{+}$stage $[86,87]$. The apparent redundancy of $\mathrm{p} 110 \delta$ and $\mathrm{p} 110 \gamma$ during $\mathrm{T}$ cell development is surprising, given that these PI3K isoforms are activated by distinct receptors. This conundrum was recently resolved by demonstrating a requirement for CXCR4 signalling in the thymus which was mostly dependent on $110 \gamma$, whereas pre-

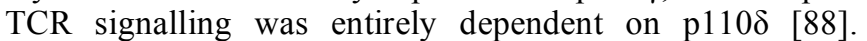

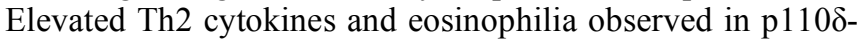
p $110 \gamma$ double deficient mice may well be a consequence of impaired $\mathrm{T}$ cell development and subsequent lymphopenia induced proliferation of the few $\mathrm{T}$ cell that do develop [85].

$\mathrm{T}$ helper cell differentiation and cytokine production is PI3K dependent in mice and humans as demonstrated by the ability of $\mathrm{p} 110 \delta$-selective inhibitors to block IFN- $\gamma$, IL-4 and IL-17 indicating that PI3K function is required in differentiated $\mathrm{T}$ helper cells [71]. Akt and Foxo signalling downstream of the TCR and CD28 is attenuated in $\mathrm{p} 110 \delta^{\mathrm{D} 910 \mathrm{~A}}$ mice with impaired differentiation along the Th1 and Th2 lineages [76] and $\mathrm{p} 110 \delta^{\mathrm{D} 910 \mathrm{~A}}$ mice exhibited significantly decreased Th2 cytokine responses and were 


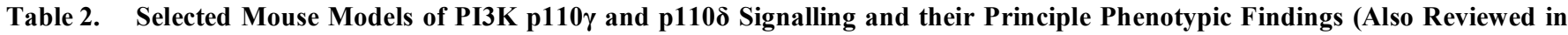
$[90-92]) \cdot$ p110 $^{\mathrm{D} 910 \mathrm{~A}}$ Mice Harbour a Point Mutation Rendering the Kinase Inactive

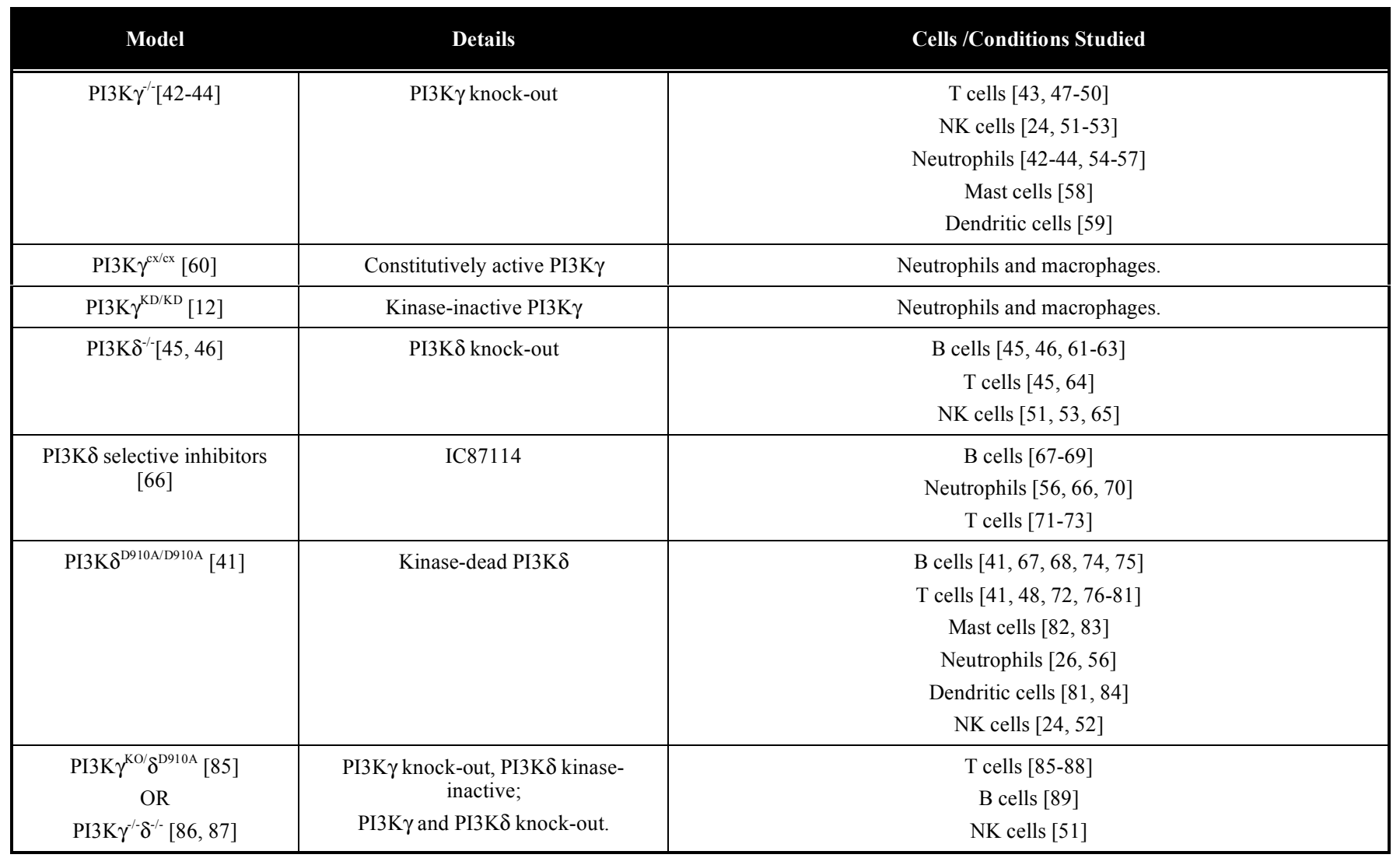

protected against eosinophilic airway inflammation [78]. Moreover, $\mathrm{p} 110 \delta^{\mathrm{D} 910 \mathrm{~A}}$ mice were resistant to experimental autoimmune encephalitis which was correlated with reduced numbers of Th17 cells [102].

PI3K also plays an important role in $\mathrm{T}$ follicular helper $\left(\mathrm{T}_{\mathrm{FH}}\right)$ cells, a subset of $\mathrm{T}$ cells which are critical for the provision of help to germinal centre $B$ cells during affinity maturation and for their differentiation into long-lived plasma cells [103]. $\mathrm{T}_{\mathrm{FH}}$ cells are likely to be crucial pathogenic mediators in SLE, as it is the long-lived plasma cells they create that exhibit most resistance to B cell depleting therapies and are the predominant source of highaffinity pathogenic autoantibodies [104, 105]. The ability of the costimulatory ICOS to induce $\mathrm{T}_{\mathrm{FH}}$ cells and to promote the generation of germinal centres and high affinity, class switched antibodies is critically dependent on p110 [64, 106].

Regulatory $\mathrm{T}$ cells (Tregs) develop both in the thymus and the periphery from mature CD4 T cells and serve a critical role in controlling the adaptive immune system and preventing unrestrained inflammatory responses [107]. p $110 \delta^{\mathrm{D} 910 \mathrm{~A}}$ mice has revealed increased numbers of Tregs in the thymus, but reduced numbers in the spleen and lymph nodes implicating a role for $\mathrm{p} 110 \delta$ in the maintenance of Tregs in the periphery $[79,108]$. p110 1 -inactive Tregs also fail to suppress $\mathrm{T}$ cell proliferation in vitro, to secrete the key suppressive cytokine IL-10 and to prevent a model of

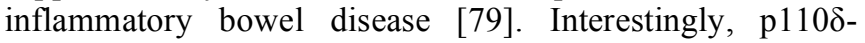
deficient mice show enhanced clearance of the protozoan parasite Leishmania major, despite a major reduction in Th1 cells [81], in part as a consequence of altered Treg function. mTOR deficient T cells display normal activation and IL-2 production on stimulation, but impaired differentiation into Th1, Th2 and Th17 cell subsets; instead T cells differentiated into Foxp3+ regulatory T cells $[2,109,110]$. Rapamycin also promotes the expansion of Tregs [111]. Moreover, Foxo transcription factors control the pivotal transcription factor Foxp3 which is both necessary and sufficient for the induction of regulatory $\mathrm{T}$ cell (Treg) function [112]. PI3K signalling can therefore suppress Foxp3 expression by activating Akt which phosphorylates and sequesters Foxo1 and Foxo3a [1]. The ability of PI3K to activate mTOR and inhibit Foxo may explain the increased abundance of Tregs in the thymus, but does not explain the paucity of Tregs in the spleen of $\mathrm{p} 110 \delta^{\mathrm{D} 910 \mathrm{~A}}$ mice $[79,108]$.

\section{PI3K IN NEUTROPHILS}

Neutrophils are the most abundant circulating phagocyte and form the cornerstone of the innate immune system, playing a central role in the destruction of invading pathogens [113]. Neutrophil dysfunction is also known to contribute to the pathogenesis of a number of autoimmune diseases, including SLE and RA. Thus, inhibition of neutrophil activation is a potential therapeutic goal in the treatment of these conditions and pathways implicated in dysfunctional intracellular signalling may provide promising routes of enquiry. 
In common with other leucocytes, the $\mathrm{p} 110 \gamma$ and $\mathrm{p} 110 \delta$ isoforms of PI3K are markedly enriched in neutrophils. However, although both $\mathrm{p} 110 \gamma$ and $\mathrm{p} 110 \delta$ are both expressed in neutrophils, the upstream RTKs and GPCRs that recruit and activate them are downstream of a markedly different array of cell surface receptors to those implicated in PI3K signalling in lymphocytes. Integrins, $\mathrm{Fc} \gamma$ receptors and cytokine receptors are key among RTK stimuli, and receptors for fMLP, C5a and $\mathrm{LTB}_{4}$ are all known to activate GPCR-mediated PI3K activity [114].

Effective neutrophil function is dependent on several related activities ranging from chemotaxis, endothelial adhesion, diapedesis, phagocytosis, activation, phagolysosomal maturation, free radical production and (later) apoptosis. Class $1 \mathrm{PI} 3 \mathrm{~K}$ control neutrophil spreading on endothelium [115], migration [57, 70] and pathogen killing [116]. In addition the class 3 PI3K VPS34 is important in phagocytosis [117].

PI3K $\gamma$ genetic knockout in mice results in fully differentiated neutrophils that fail to phosphorylate Akt and show impaired respiratory burst, motility and migration toward chemotactic stimuli, especially in vivo(42). PI3K activity through the $\mathrm{p} 110 \gamma$ isoform can contribute to cell polarisation, with $\mathrm{PIP}_{3}$ generation at the leading edge involved in actin rearrangement [54, 118]. However an important role also exists for SHIP, with $\mathrm{SHIP}^{-/-}$neutrophils demonstrating impaired localisation of Akt at the leading edge of the plasma membrane reducing motility [108].

In vitro the impairment of neutrophil directional movement by $\mathrm{p} 110 \gamma$ inactivation is exacerbated by pharmacological inhibition with the p1108-specific inhibitor IC87114 [66]. A phenotype reproduced in in vivo models of pulmonary inflammation and arthritis [119]. The effects on neutrophil migration are mediated through both reduced neutrophil tethering in TNF- $\alpha$ primed blood vessels (p110 $\gamma$ mediated) and via impaired transmigration of neutrophils

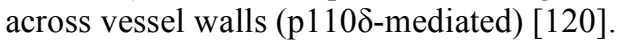

At the site of infection, neutrophils kill pathogens by generating reactive oxygen species (ROS) via the respiratory burst process. Genetic inactivation of p110 $\gamma$ impaired ROS production in neutrophils in response to $\mathrm{fMLP}(42)$, in keeping with a likely impairment in killing of phagocytosed pathogens. p1 $10 \delta$ is also implicated in neutrophil respiratory burst in human (but not mouse) neutrophils stimulated with fMLP, where initial transient p110 $\gamma$-dependent PIP3 generation is followed by more sustained p $110 \delta$-mediated PIP3 production [56].

Neutrophil PI3K signalling is not wholly dependent on $\mathrm{p} 110 \gamma$ and $\mathrm{p} 110 \delta$ as the $\mathrm{p} 110 \beta$ isoform has also been shown to play a critical role in FcyR-dependent activation of mouse neutrophils by IgG immune complexes. ROS production in response to low concentrations of immune complexes is completely blocked by $110 \beta$ inhibition. At higher concentrations of immune complexes, combined inhibition of $\mathrm{p} 110 \beta$ and $\mathrm{p} 110 \delta$ was required to achieve the same suppression of ROS. In an in vivo model of FcyR-dependent

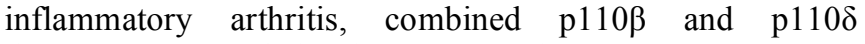
deficiency provided almost complete protection from pathology [26].
The diverse and complementary influences of the various isoforms of PI3K on neutrophils suggest that drugs targeting p110 $\gamma$ and $110 \delta$ may exert immunosuppressive effects that could be of value in conditions in which neutrophil activation play a prominent role, and that strategies which both target single isoforms and combination inhibition may offer therapeutic benefit. Accompanying this potential is the concern that PI3K inhibition could increase susceptibility to opportunistic infections as suggested by the increased susceptibility to Streptococcus pneumoniae pneumonia seen in $\mathrm{p} 110 \gamma^{-/-}$mice [121]

\section{PI3K IN OTHER CELLS OF THE IMMUNE SYSTEM}

Mast cells reside in tissues such as the skin and mucosa and are characterised by the ability to release large amounts of heparin and histamine from their cytoplasmic granules. This release is mediated by the RTKs c-Kit and FceR1 which couple to the $\mathrm{p} 110 \delta$ isoform of PI3K. Mast cell degranulation plays an important role in allergic inflammatory disorders such as asthma and allergic rhinitis, and in anaphylaxis. Mice with inactive p110 and those treated with a pharmacological $\mathrm{p} 110 \delta$ inhibitor are protected from passive cutaneous anaphylaxis [82, 83]. p110 inhibition and $\mathrm{p} 110 \gamma^{-/-}$mice have normal early mast cell responses but a reduced phenotype at later stages, suggesting an impairment in signal amplification [58].

Dendritic cells (DCs) are potent antigen-presenting cells with roles in initiating cellular and humoral immune responses and in tolerance induction. Prior to antigen encounter DCs reside in tissues in an immature state, becoming activated upon contact with antigen in the context of inflammatory or pathogen-derived stimuli. This activation leads to DC migration to the T-cell rich paracortex of draining lymph nodes where they present antigen to CD4 T cells, initiating immune responses. DCs have been studied in p110 $\gamma^{-/-}$mice, in which they demonstrate normal differentiation but have markedly impaired migration. This results in a reduction in severity of contact hypersensitivity in $\mathrm{p} 110 \gamma^{-/-}$mice [59] and may delay symptoms in an experimental autoimmune encephalitis [122]. The role of PI3K is not limited to $\mathrm{p} 110 \gamma ; \mathrm{p} 110 \delta$ has a key role in promoting IL-6 release in response to cKit stimulation on dendritic cells by cholera toxin [84].

Macrophages coordinate $\mathrm{C} 5 \mathrm{a}$ and $\mathrm{Fc} \gamma \mathrm{R}$ signalling through the $\mathrm{p} 110 \gamma$ and $\mathrm{p} 110 \delta$ isoforms of PI3K. In a mouse model of the passive reverse lung Arthus reaction, genetic deletion of $\mathrm{p} 110 \gamma$ blocked $\mathrm{C} 5 \mathrm{aR}$ signalling crucial for activation of lung macrophages. However C5a production occurred normally in $\mathrm{p} 110 \gamma^{-/}$mice but was impaired in $\mathrm{p} 110 \delta^{-/-}$mice, which demonstrated resistance to acute immune complex-induced lung injury, thus defining p $110 \delta$ as a crucial element of $\mathrm{F} c \gamma \mathrm{R}$ signalling in the production of C5a [123].

Eosinophils infiltrate release pro-inflammatory cytokines and ROS in response to $\mathrm{IgE}$ immune complexes. Studies using the pan-PI3K inhibitor wortmannin have implicated PI3K in eosinophil chemotaxis and release from the bone marrow [124], and inhibitor-treated mice show a reduction in eosinophilia in allergen-induced bronchial inflammation [125]. Subsequent studies suggest that $\mathrm{p} 110 \gamma$ is the isoform most likely mediating this effect $[126,127]$. However, some 
Table 3. Murine Models of PI3K Activity in RA

\begin{tabular}{|c|c|c|}
\hline Model & Details & Isoforms Studied \\
\hline CIA & Markedly reduced joint inflammation & $\begin{array}{l}\text { Pharmacological p110 } \gamma \text { or pan-PI3K inhibition }[144, \\
146]\end{array}$ \\
\hline$\alpha$ CII-IA & $\begin{array}{c}\text { Markedly reduced joint inflammation, reduced neutrophil } \\
\text { invasion }\end{array}$ & Pharmacological and genetic p110 $\gamma$ inhibition [144] \\
\hline Antigen-induced arthritis & $\begin{array}{l}\text { Reduced joint inflammation, reduced activation and } \\
\text { migration of phagocytes }\end{array}$ & Pharmacological and genetic p110 $\gamma$ inhibition [147] \\
\hline $\mathrm{K} / \mathrm{BxN}$ & 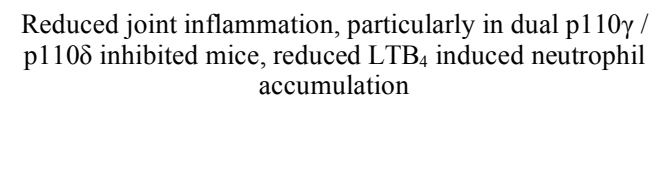 & 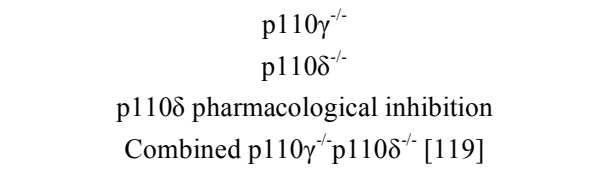 \\
\hline
\end{tabular}

data suggest that combined PI3K inhibition may also have

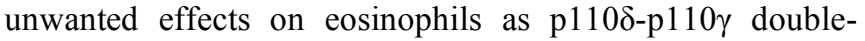
mutant mice developed marked eosinophilic infiltration in multiple organs, with increased serum IgE, IL-4 and IL-5 [85].

\section{PERTURBATIONS OF THE PI3K PATHWAY IN RHEUMATIC DISEASES}

\section{Rheumatoid Arthritis}

RA is characterised by synovitis and systemic inflammation secondary to autoantibody production (particularly rheumatoid factor and citrullinated peptide). It is common, disabling and can have a significant impact on patients' quality of life [128]. Current treatment strategies centre on the use of disease-modifying antirheumatic drugs (DMARDs) as a first line treatment [129-132]. However, these are agents are non-specific, may be associated with problematic side effects and disease flares occur despite such treatments. Advances in RA therapies have been considerable in recent years with a number of biological agents receiving approval. These include TNF inhibitors [133], a CTLA-4 fusion protein (abatacept) [134], a B cell depleting CD20 antibody (rituximab) [135] and an IL-6 inhibitor (tocilizumab) [136]. Although these biological treatments have demonstrated impressive efficacy in subsets of patients, their widespread use remains limited by cost and susceptibility to infection [137]. Furthermore, not all patients respond to such treatments. Thus there remains an unmet need to develop further targeted therapies that may benefit patients with RA.

The underlying pathogenesis of RA is complex and can involve inappropriate activation of cells of both the innate and adaptive immune systems with $\mathrm{T}$ cells [138], B cells [139], dendritic cells [140], mast cells [141] and neutrophils [142] all implicated in disease models and human pathology.

RA is thought to be initiated in peripheral lymphoid organs by the presentation of self-antigens to autoreactive $\mathrm{T}$ cells. This in turn prompts activation of autoreactive B cells to produce autoantibodies that form immune complexes. These deposit in joints triggering the release of proinflammatory cytokines from neutrophils, macrophages and mast cells that cause inflammatory cell migration and pannus formation. Tissue damage then results from the activation of synoviocytes which invade cartilage and osteoclasts which increase bone resorption [143]. Over time irreversible bone and cartilage destruction occurs, leading to accrual of disability [128].

The $\mathrm{p} 110 \gamma$ and $\mathrm{p} 110 \delta$ isoforms of PI3K have attracted considerable interest as pharmacological targets in the treatment of RA given the known effects of their inhibition on a variety of immune cells [4] (Table 3). PI3K $\gamma$ blockade by both genetic and pharmacological approaches suppresses joint inflammation and damage in two murine models of RA - collagen-induced arthritis (CIA) and $\alpha$ CII-induced arthritis $(\alpha C I I-I A)$. In the CIA model mice treated with AS-605240 (a p110 $\gamma$-selective inhibitor) showed a significant reduction in joint inflammation with a near normal mean paw thickness. There was also marked amelioration of histological measures of synovial inflammation, cartilage erosion and neutrophil infiltration in arthritic joints. Similar findings were observed in the $\alpha$ CII-IA model using both mice with genetically inactive $\mathrm{p} 110 \gamma$ and pharmacological inhibition with the same small molecule inhibitor. Similarly p1 $10 \gamma$-deficient and p110 $\gamma$ inhibitor treatment ameliorated disease in the early stages of antigen-induced arthritis [144]. A further role for $\mathrm{p} 110 \gamma$ is seen in the regulation of synovial fibroblasts in RA, in which $\mathrm{p} 110 \gamma$ deficiency leads to a milder inflammatory erosive arthritis and TNF- $\alpha$ mediated cartilage destruction. p110 $\gamma$ is highly expressed in the synovium of patients with RA [145].

The role of $\mathrm{p} 110 \delta$ in RA has also been investigated. In a study utilising the neutrophil-dependent $\mathrm{K} / \mathrm{BxN}$ serum transfer model of arthritis, genetic and pharmacological inactivation of $\mathrm{p} 110 \delta$ reduced joint injury. Interestingly the effect of pharmacological inhibition of p $110 \delta$ in mice with genetic inactivation of $110 \gamma$ was also assessed and was found to totally prevent any macroscopic evidence of joint inflammation or histological evidence of bone or joint damage. Consistent with this a marked reduction in neutrophil infiltration was observed, raising the possibility that combined $\mathrm{p} 110 \gamma$ and $\mathrm{p} 110 \delta$ inhibition may potentially offer additive therapeutic benefits [119]. In a separate study, the pan-specific PI3K inhibitor ZST474 was shown to alleviate CIA by a mechanism that the authors suggested also involved the inhibition of osteoclast formation [146].

Given the 70 million years of divergent evolution separating rodents and Homo sapiens, murine models can only ever reflect human disease imperfectly. Although these models serve a vital role in supporting the development of 
isoform specific inhibitors for human use, certain pathophysiological differences between these models and human disease may be pertinent to PI3K signalling in particular. The CIA model, considered the most faithful model of human disease, shares many similarities with rheumatoid arthritis - an association with certain MHC Class II haplotypes, a breach of tolerance with generation of autoantibodies, and comparable clinical features. Yet the studies appraising p110 $\gamma$ inhibition focussed on the effect of reduced neutrophil and monocyte chemotaxis. In humans there is evidence to suggest that retention of inflammatory cells within the rheumatoid joint is a more critical factor than the rate of synovial infiltration [148]. Furthermore neutrophil accumulation is a prominent feature in CIA whereas in the rheumatoid synovium macrophages comprise the major phagocytic population. Additionally, collagen autoantibodies are critical players in CIA pathology whilst human RA patients do not form autoantibodies against this antigen, and it is not certain that $\mathrm{B}$ and $\mathrm{T}$ cell antigen receptor signalling is actively engaged in established rheumatoid arthritis. Similar drawbacks exist with the $\mathrm{K} / \mathrm{BxN}$ and serum transfer models of arthritis which again depend on non-RA autoantibodies and neutrophil infiltration [149, 150]. Nevertheless, murine models have been invaluable in supporting the progress of many recent drugs to the clinic and will continue to serve an essential complementary role to human ex vivo studies in the preclinical arena.

In vitro studies on human cells using $\mathrm{p} 110 \delta$ inhibition showed that $\mathrm{T}$ cells from healthy volunteers stimulated with anti-CD3 and anti-CD28 had reduced Akt phosphorylation and IL-17, TNF- $\alpha$ and IFN- $\gamma$ production. Similar results were found in mononuclear cells isolated from the synovial fluid of patients with reactive arthritis, with IFN- $\gamma$, TNF- $\alpha$ and IL-17 production blocked to a similar extent to that observed with ciclosporin [71]. The effect of inhibiting PI3K with the broad spectrum inhibitors LY294002 and wortmannin has also been evaluated. PI3K was shown to be necessary for TGF- $\beta$ mediated proliferation and resistance to Fas-mediated apoptosis in patient synovial fibroblasts [151] and for the ability of anti-CD3-stimulated RA patient synovial $\mathrm{T}$ cells to induce monocyte TNF- $\alpha$ production [152]. Further interest in PI3K signalling was stimulated by the observation that RA patient synovial fibroblasts have markedly reduced expression of PTEN, in keeping with over activity of signalling in this axis [153]. In addition, macrophages have PI3K-dependent expression of the prosurvival protein Mcl-1, and LY294002 induces apoptotic death in RA patient synovial macrophages [154]. PI3K signalling is also necessary for $\mathrm{T}$ cell-induced IL-10 (an inhibitory cytokine) production by macrophages [155].

Given that drugs that target innate and adaptive immune responses have both shown efficacy in the clinic, the

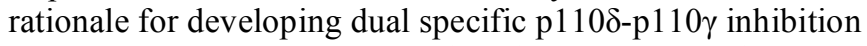
in RA seems strong [156]. Studies that investigate the effect of isoform-specific inhibitors (both p110 $\gamma$ and $\mathrm{p} 110 \delta$ individually and together) on patient-derived samples are needed to combine the encouraging findings from murine models with the known effects of pan-PI3K inhibition seen in earlier studies on patient samples.

\section{SYSTEMIC LUPUS ERYTHEMATOSUS}

SLE is a clinically and genetically heterogeneous autoimmune condition that displays a striking gender disparity, with females about nine times more likely to be affected than males. Common features include inflammatory arthritis, glomerulonephritis and a photosensitive rash, although numerous other tissues may be involved including the brain, lungs, heart and serosa. Significant advances in treatment have been achieved despite a 50 year period in which no new drugs were licensed for SLE. In the $1950 \mathrm{~s}$ there was a $50 \%$ survival at 4 years, compared to an $80 \% 15$ year survival rate today [157]. However the morbidity associated with SLE remains substantial, with patients suffering recurrent disease flares necessitating potent immunosuppression to achieve remission. As a result, a patient diagnosed with SLE at the age of 20 years still has a 1 in 6 chance of dying by the age of 35 [158].

The central pathogenic process in SLE is a loss of tolerance to nuclear antigens [159] such as chromatin, ribonucleoproteins (RNP's) and DNA. This results in the production of autoantibodies, that subsequently give rise to immune complex deposition in target organs. These deposited immune complexes initiate complement activation and cross-link Fc receptors on tissue macrophages and plasmacytoid dendritic cells, perpetuating the inflammatory response. An important component of this inflammatory response is IFN- $\alpha$ which promotes autoreactive $\mathrm{T}$ cell activation and $\mathrm{B}$ cell maturation and differentiation, resulting in self-perpetuating disease progression. Further actions of IFN- $\alpha$ include activation of neutrophils with the release of neutrophil extracellular traps (NETs), a process designed to entrap pathogens and facilitate their killing. In SLE this process further exacerbates IFN- $\alpha$ production driving disease flares and inflammation.

Current treatments are based on broadly acting immunosuppressants such as corticosteroids, azathioprine, mycophenolate and methotrexate but these drugs may be associated with problematic side effects. The recent approval by the FDA of the anti-BAFF monoclonal antibody belimumab for the treatment of SLE represents the first and only new treatment and has proven informative - not only in demonstrating the effectiveness of B cell targeted therapies but also in how to best design clinical trials for this condition characterised by high phenotypic heterogeneity $[160,161]$. Initially belimumab failed at phase II to meet its co-primary endpoints of reduction in Safety of Estrogens in LupusErythematosus National Assessment-Systemic Lupus Erythematosus Disease Activity Index (SELENA-SLEDAI) score at week 24 and prolongation of time to first flare at 52 weeks. Belimumab's eventual success depended on the identification of a subset of patients with seropositive SLE that demonstrated reduced and stabilised disease activity, prompting the continuation of this study [162]. At phase III seropositive SLE patients randomised to belimumab demonstrated significantly higher SLE Responder Index (SRI) rates compared to placebo controls at 52 weeks and more had reductions of a least four points in their SELENASLEDAI scores at the same time point [160]. 
Table 4. Murine Models of PI3K Activity in SLE

\begin{tabular}{|c|c|c|}
\hline Model & Details & Isoforms Studied \\
\hline $\begin{array}{l}\text { Class 1A PI3K induced SLE (p65 regulatory subunit } \\
\text { renders class } 1 \mathrm{~A} \text { PI3K constitutively active, inducing SLE) }\end{array}$ & $\begin{array}{l}\text { Prolonged lifespan, reduced CD4 cell survival, } \\
\text { autoantibodies and glomerulonephritis }\end{array}$ & $\begin{array}{l}\text { Genetic and pharmacological } \\
\text { inhibition of } \mathrm{p} 110 \gamma(169)\end{array}$ \\
\hline $\mathrm{MRL}^{\mathrm{Ipr}}$ & $\begin{array}{l}\text { Prolonged lifespan and reduced glomerulonephritis, } \\
\text { reduced lymphoid cells and autoantibodies }\end{array}$ & $\begin{array}{l}\text { Pharmacological inhibition of } \\
\text { p1 } 10 \gamma(168)\end{array}$ \\
\hline
\end{tabular}

Table 5. Other Autoimmune and Inflammatory Conditions with Preclinical Evidence for PI3K Inhibition as a Potential Treatment

\begin{tabular}{|c|c|}
\hline Model & Isoforms Investigated and References \\
\hline Passive cutaneous anaphylaxis & $\mathrm{p} 110 \delta[82,83], \mathrm{p} 110 \gamma[58]$ \\
\hline Asthma/airway inflammation & $\mathrm{p} 110 \delta[78,147,175-178], \mathrm{p} 110 \gamma[127,179]$, dual $\mathrm{p} 110 \delta$ and $\mathrm{p} 110 \gamma$ inhibition [180] \\
\hline Experimental autoimmune encephalitis & $\mathrm{p} 110 \delta[102]$ and $\mathrm{p} 110 \gamma[109,122]$ \\
\hline Atherosclerosis & $\mathrm{p} 110 \gamma[181]$ \\
\hline Contact and delayed type hypersensitivity & $\mathrm{p} 110 \delta$ [71], p110y[59] \\
\hline
\end{tabular}

$B$ cell activating factor belonging to the TNF family (BAFF) signalling is impaired in p110 $\delta$-deficient B cells, resulting in reduced survival, growth and proliferation in vitro [63]. p110 $\delta$ has been found to be associated with the BAFF receptor, although another report suggested that the ability of BAFF to activate the PI3K pathway was indirectly mediated by an NF- $\kappa \mathrm{B}$ target gene $[163,164]$. Regardless of the precise mechanism involved, these data raise the possibility that one mechanism of $\mathrm{p} 110 \delta$ inhibitors may be to attenuate BAFF-dependent pathology in SLE.

Several genetically engineered mouse strains with enhanced PI3K/Akt/mTOR signalling have been noted to develop a lymphoproliferative syndrome with autoimmune features resembling SLE (Table 4) [28-30, 165-167]. Conversely, promising results have been obtained from attempts to inhibit PI3K activity in mouse models of SLE $[168,169]$. Inhibition of $\mathrm{p} 110 \gamma$ in the SLE-prone MRL ${ }^{1 p r}$ strain with the inhibitor AS605240 attenuated glomerulonephritis and extended lifespan, with $88 \%$ of treated mice surviving five months compared with only $60 \%$ of controls. Treated mice also had marked reductions in splenocyte numbers, lower DNA-specific autoantibody levels, less severe histopathological features of glomerulonephritis and a reduction in pathogenic $\mathrm{CD} 4^{+}$ memory T cells [168].

In parallel experiments, the same authors used a second model of SLE caused by constitutive activation class $1 \mathrm{~A}$ PI3K, and crossed these mice with p110 $\gamma$ deficient mice to assess the ability of $\mathrm{p} 110 \gamma$ to ameliorate lupus-like disease [169]. In this experimental system p110 $\gamma$-deficient mice showed significantly prolonged survival with $70 \%$ still healthy at 16 months of age, compared with only $20 \%$ of SLE-prone controls, although $\mathrm{T}$ cell invasion and lymphoproliferation were unimpaired.

The role of $\mathrm{p} 110 \delta$-mediated PI3K signalling in SLE has not yet been directly studied in mouse models but is a promising area for future investigation. In San Roque mice, a lupus like syndrome results from the expansion of $\mathrm{T}_{\mathrm{FH}}$ cells secondary to elevated expression of the costimulatory receptor ICOS $[170,171]$. In humans, an increased number of circulating $\mathrm{T}_{\mathrm{FH}}$ cells has been observed in a subset of patients with SLE with more severe pathology [172]. p110

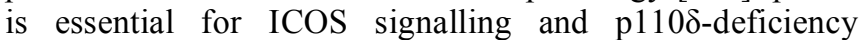
severely impairs the development of $\mathrm{T}_{\mathrm{FH}}$ cells $[64,106]$. Thus $\mathrm{p} 110 \delta$ inhibitors may provide a means of blocking the development or maintenance of disease-associated $\mathrm{T}_{\mathrm{FH}}$ cells in patients with lupus.

PI3K activity was found to be higher in T cells from SLE patients than from normal controls and this increased PI3K activity appeared to be provided by elevated $\mathrm{p} 110 \delta$ activity [173]. Interestingly, the PI3K activity was higher in T cells from patients SLEDAI scores of more than 4. The authors further provided evidence that the increased PI3K activity rendered the SLE T cells resistant to activation induced cell death. In a study of lipid uptake in SLE patient macrophages, scavenger receptor up-regulation in response to IFN- $\alpha$ was blocked by inhibition of the PI3K/Akt pathway with the panPI3K inhibitor LY294002 suggesting that PI3K signalling may contribute to foam cell formation. This could implicate a role for $\mathrm{PI} 3 \mathrm{~K}$ in the excess cardiovascular morbidity suffered by patients with SLE [174].

In summary, given the central role played by PI3Ks in T cell-dependent humoral immune responses and $\mathrm{B}$ cell homeostasis as well as promising pre-clinical studies suggests a strong rationale for the development of PI3K inhibitors for SLE.

\section{OTHER AUTOIMMUNE AND INFLAMMATORY DISEASES}

PI3K inhibitors have potential as treatments for a wide range of autoimmune and inflammatory conditions. Reviewing the preclinical evidence for all of these in details is beyond the scope of this article, but we have included a list of animal models in which p $110 \gamma$ and $\mathrm{p} 110 \delta$ inhibitors or genetic knock-outs and knock-ins have shown efficacy in pre-clinical models in the table below (Table 5). 


\section{Translating the Bench-Top Science into Bedside Treatments}

Selecting drugs to make the transition from preclinical models of diseases to effective therapies for human diseases remains a significant challenge. There is a substantial unmet need for new drugs to treat patients with RA resistant to antiTNF based therapies, and SLE patients intolerant of (or poorly responsive to) current, commonly used immunosuppressants.

The promising results from CAL-101 (the first in class p1108 inhibitor) in its trials for refractory CLL and indolent non-Hodgkin's lymphoma provides some reassurance about the safety profile of drugs in this family [16, 17]. p110 inhibitors are also being developed for other indications, including rheumatic diseases described in this review. Indeed a striking increase in patent applications for inhibitors claiming p110 selectivity has occurred over the last few years [182].

Ongoing challenges facing the academic and pharmaceutical industries in the advancement of PI3K inhibitors include difficulties in synthesising highly specific p110 $\gamma$ inhibitors [156, 183]. The availability of crystal structures of $\mathrm{p} 110 \delta$ and $\mathrm{p} 110 \gamma$ in complex with different inhibitors will no doubt accelerate progress in developing ever more selective and potent PI3K inhibitors [21, 112]. Whether dual inhibitors of $\mathrm{p} 110 \delta$ and $\mathrm{p} 110 \gamma$ offer advantages over single isoform-selective inhibitors used alone or in combination will need to be explored further [156].

The wealth of preclinical evidence for $\mathrm{p} 110 \gamma$ and $\mathrm{p} 110 \delta$ inhibition in autoimmune and inflammatory conditions suggests significant potential for patient benefit. The results of early clinical trials are anticipated with great interest as the roles of these immunologically important kinases become more clearly defined in humans.

\section{ACKNOWLEDGEMENTS}

We would like to thank Dalya Soond for constructive comments on the manuscript.

EBH is supported by the Wellcome Trust Translational Medicine and Therapeutics (TMAT) which is also funded by GlaxoSmithKline. Research in the Okkenhaug laboratory is supported by the BBSRC, Wellcome Trust and GlaxoSmithKline. KO is a consultant for GlaxoSmithKline.

\section{CONFLICT OF INTEREST}

The authors confirm that this article content has no conflicts of interest.

\section{ADDENDUM}

Since this manuscript was accepted for publication key papers have shown that $\mathrm{p} 110 \delta$ is a key regulator of synoviocytes function in rheumatoid arthritis. Using qPCR and immunohistochemistry the authors showed that $\mathrm{p} 110 \delta$ mRNA and protein expression levels were higher in the synovial lining of patients with rheumatoid arthritis compared to controls with osteoarthritis. They went on to demonstrate that select pharmacological inhibition of $\mathrm{p} 110 \delta$ could block PGDF and TNF-induced Akt activation [184]. Separately, the role of p110 in autoimmunity has been investigated using a Lyn-deficient mouse. These mice develop autoreactive antibodies, glomerulonephritis and generalised inflammation secondary to a hyperactivated B cell phenotype with a phenotype that has certain similarities to human SLE. Mice heterozygous for the $\mathrm{p} 110 \delta^{\mathrm{D} 910 \mathrm{~A}}$ mutation had significantly attenuated disease parameters. Interestingly this protection was mediated in part as a consequence of greatly diminished $\mathrm{T}$ cell activation, despite the fact that Lyn is not expressed in these cells - implying an impairment of $\mathrm{p} 110 \delta$ activity restricts the ability of $\mathrm{T}$ cells to induce B cell class switching and contribute to disease [185].

\section{REFERENCES}

[1] Nathan C, Ding A. Nonresolving inflammation. Cell 2010; 140(6): 871-82.

[2] Daniel C, Nolting J, von Boehmer H. Mechanisms of self-nonself discrimination and possible clinical relevance. Immunotherapy 2009; 1(4): 631-44.

[3] Rai E, Wakeland EK. Genetic predisposition to autoimmunity-what have we learned? Semin Immunol 2011; 23(2): 67-83.

[4] Rommel C, Camps M, Ji H. PI3K delta and PI3K gamma: partners in crime in inflammation in rheumatoid arthritis and beyond? Nat Rev Immunol 2007; 7(3): 191-201.

[5] Vanhaesebroeck B, Guillermet-Guibert J, Graupera M, Bilanges B. The emerging mechanisms of isoform-specific PI3K signalling. Nat Rev Mol Cell Biol 2010; 11(5): 329-41.

[6] Cantley LC. The phosphoinositide 3-kinase pathway. Science 2002; 296(5573): 1655-7.

[7] Hawkins PT, Anderson KE, Davidson K, Stephens LR. Signalling through Class I PI3Ks in mammalian cells. Biochem Soc Trans 2006; 34(Pt 5): 647-62.

[8] Engelman JA, Luo J, Cantley LC. The evolution of phosphatidylinositol 3-kinases as regulators of growth and metabolism. Nat Rev Genet 2006; 7(8): 606-19.

[9] Eickholt BJ, Ahmed AI, Davies M, et al. Control of axonal growth and regeneration of sensory neurons by the p110delta PI 3-kinase. PLoS One 2007; 2(9): e869.

[10] Sawyer C, Sturge J, Bennett DC, et al. Regulation of breast cancer cell chemotaxis by the phosphoinositide 3-kinase pl10delta. Cancer Res 2003; 63(7): 1667-75.

[11] Maxwell MJ, Tsantikos E, Kong AM, Vanhaesebroeck B, Tarlinton DM, Hibbs ML. Attenuation of phosphoinositide 3-kinase delta signaling restrains autoimmune disease. J Autoimmun 2012; 38(4): 381-91.

[12] Patrucco E, Notte A, Barberis L, S et al. PI3Kgamma modulates the cardiac response to chronic pressure overload by distinct kinase-dependent and -independent effects. Cell 2004; 118(3): 37587.

[13] Crackower MA, Oudit GY, Kozieradzki I, et al. Regulation of myocardial contractility and cell size by distinct PI3K-PTEN signaling pathways. Cell 2002; 110(6): 737-49.

[14] Perino A, Ghigo A, Ferrero E, et al. Integrating cardiac PIP3 and cAMP signaling through a PKA anchoring function of p110gamma. Mol Cell 2011; 42(1): 84-95.

[15] Lannutti BJ, Meadows SA, Herman SE, et al. CAL-101, a p110delta selective phosphatidylinositol-3-kinase inhibitor for the treatment of B-cell malignancies, inhibits PI3K signaling and cellular viability. Blood 2011; 117(2): 591-4.

[16] Richards L, Ferreira DM, Miyaji EN, Andrew PW, Kadioglu A. The immunising effect of pneumococcal nasopharyngeal colonisation; protection against future colonisation and fatal invasive disease. Immunobiology 2010; 215(4): 251-63.

[17] Roche AM, King SJ, Weiser JN. Live attenuated Streptococcus pneumoniae strains induce serotype-independent mucosal and systemic protection in mice. Infect Immun 2007; 75(5): 2469-75.

[18] Furman RR, Byrd JC, Brown JR, et al. CAL-101, an isoformselective inhibitor of phosphatidylinositol 3-kinase P110\{delta\}, demonstrates clinical activity and pharmacodynamic effects in patients with relapsed or refractory chronic lymphocytic leukemia. ASH Annu Meet Abst 2010; 116(21): 55.

[19] Vanhaesebroeck B, Vogt PK, Rommel C. PI3K: from the bench to the clinic and back. Curr Top Microbiol Immunol 2010; 347: 1-19.

[20] Ouyang W, Beckett O, Flavell RA, Li MO. An essential role of the Forkhead-box transcription factor Foxol in control of $\mathrm{T}$ cell homeostasis and tolerance. Immunity 2009; 30(3): 358-71. 
[21] Walker EH, Pacold ME, Perisic O, et al. Structural determinants of phosphoinositide 3-kinase inhibition by wortmannin, LY294002, quercetin, myricetin, and staurosporine. Mol Cell 2000; 6(4): 90919.

[22] Delgado P, Cubelos B, Calleja E, et al. Essential function for the GTPase TC21 in homeostatic antigen receptor signaling. Nat Immunol 2009; 10(8): 880-8.

[23] Reif K, Okkenhaug K, Sasaki T, Penninger JM, Vanhaesebroeck B, Cyster JG. Cutting edge: differential roles for phosphoinositide 3kinases, p110gamma and p110delta, in lymphocyte chemotaxis and homing. J Immunol 2004; 173(4): 2236-40.

[24] Saudemont A, Garcon F, Yadi H, et al. p110gamma and p110delta isoforms of phosphoinositide 3-kinase differentially regulate natural killer cell migration in health and disease. Proc Natl Acad Sci USA 2009; 106(14): 5795-800.

[25] Guillermet-Guibert J, Bjorklof K, Salpekar A, et al. The p110beta isoform of phosphoinositide 3-kinase signals downstream of $\mathrm{G}$ protein-coupled receptors and is functionally redundant with p110gamma. Proc Natl Acad Sci USA 2008; 105(24): 8292-7.

[26] Kulkarni S, Sitaru C, Jakus Z, et al. PI3K \{beta\} plays a critical role in neutrophil activation by immune complexes. Sci Signal 2011; 4(168): ra23.

[27] Schmid MC, Avraamides CJ, Dippold HC, et al. Receptor tyrosine kinases and TLR/IL1Rs unexpectedly activate myeloid cell PI3Kgamma, a single convergent point promoting tumor inflammation and progression. Cancer Cell 2011; 19(6): 715-27.

[28] Browne CD, Del Nagro CJ, Cato MH, Dengler HS, Rickert RC. Suppression of phosphatidylinositol 3,4,5-trisphosphate production is a key determinant of B cell anergy. Immunity 2009; 31(5): 74960.

[29] Di Cristofano A, Kotsi P, Peng YF, Cordon-Cardo C, Elkon KB, Pandolfi PP. Impaired Fas response and autoimmunity in Pten+/mice. Science 1999; 285(5436): 2122-5.

[30] Suzuki A, Yamaguchi MT, Ohteki T, et al. T cell-specific loss of Pten leads to defects in central and peripheral tolerance. Immunity 2001; 14(5): 523-34.

[31] Miletic AV, Anzelon-Mills AN, Mills DM, et al. Coordinate suppression of B cell lymphoma by PTEN and SHIP phosphatases. J Exp Med 2010; 207(11): 2407-20.

[32] Ong CJ, Ming-Lum A, Nodwell M, et al. Small-molecule agonists of SHIP1 inhibit the phosphoinositide 3-kinase pathway in hematopoietic cells. Blood 2007; 110(6): 1942-9.

[33] Manning BD, Cantley LC. AKT/PKB signaling: navigating downstream. Cell 2007; 129(7): 1261-74.

[34] Saunders RN, Metcalfe MS, Nicholson ML. Rapamycin in transplantation: a review of the evidence. Kidney Int 2001; 59(1): 3-16.

[35] Bruyn GA, Tate G, Caeiro F, et al. Everolimus in patients with rheumatoid arthritis receiving concomitant methotrexate: a 3month, double-blind, randomised, placebo-controlled, parallelgroup, proof-of-concept study. Ann Rheum Dis 2008; 67(8): 10905.

[36] Fernandez D, Bonilla E, Mirza N, Niland B, Perl A. Rapamycin reduces disease activity and normalizes $\mathrm{T}$ cell activation-induced calcium fluxing in patients with systemic lupus erythematosus. Arthritis Rheum 2006; 54(9): 2983-8.

[37] Bi L, Okabe I, Bernard DJ, Wynshaw-Boris A, Nussbaum RL. Proliferative defect and embryonic lethality in mice homozygous for a deletion in the p110alpha subunit of phosphoinositide 3kinase. J Biol Chem 1999; 274(16): 10963-8.

[38] Bi L, Okabe I, Bernard DJ, Nussbaum RL. Early embryonic lethality in mice deficient in the p110beta catalytic subunit of PI 3kinase. Mamm Genome 2002; 13(3): 169-72.

[39] Foukas LC, Claret M, Pearce W, et al. Critical role for the p110alpha phosphoinositide-3-OH kinase in growth and metabolic regulation. Nature 2006; 441(7091): 366-70.

[40] Ciraolo E, Iezzi M, Marone R, et al. Phosphoinositide 3-kinase p110beta activity: key role in metabolism and mammary gland cancer but not development. Sci Signal 2008; 1(36): ra3.

[41] Okkenhaug K, Bilancio A, Farjot G, et al. Impaired B and T cell antigen receptor signaling in p110delta PI 3-kinase mutant mice. Science 2002; 297(5583): 1031-4.

[42] Hirsch E, Katanaev VL, Garlanda C, et al. Central role for G protein-coupled phosphoinositide 3-kinase gamma in inflammation. Science $2000 ; 287(5455): 1049-53$.
[43] Sasaki T, Irie-Sasaki J, Jones RG, et al. Function of PI3Kgamma in thymocyte development, $\mathrm{T}$ cell activation, and neutrophil migration. Science 2000; 287(5455): 1040-6.

[44] Li Z, Jiang H, Xie W, Zhang Z, Smrcka AV, Wu D. Roles of PLCbeta2 and -beta3 and PI3Kgamma in chemoattractant-mediated signal transduction. Science 2000; 287(5455): 1046-9.

[45] Jou ST, Carpino N, Takahashi Y, et al. Essential, nonredundant role for the phosphoinositide 3-kinase p110delta in signaling by the B-cell receptor complex. Mol Cell Biol 2002; 22(24): 8580-91.

[46] Clayton E, Bardi G, Bell SE, et al. A crucial role for the p110delta subunit of phosphatidylinositol 3-kinase in B cell development and activation. J Exp Med 2002; 196(6): 753-63.

[47] Thomas MS, Mitchell JS, DeNucci CC, Martin AL, Shimizu Y. The p110gamma isoform of phosphatidylinositol 3-kinase regulates migration of effector $\mathrm{CD} 4 \mathrm{~T}$ lymphocytes into peripheral inflammatory sites. J Leukoc Biol 2008; 84(3): 814-23.

[48] Garcon F, Patton DT, Emery JL, et al. CD28 provides T-cell costimulation and enhances PI3K activity at the immune synapse independently of its capacity to interact with the p85/p110 heterodimer. Blood 2008; 111(3): 1464-71.

[49] Alcazar I, Marques M, Kumar A, et al. Phosphoinositide 3-kinase gamma participates in $\mathrm{T}$ cell receptor-induced $\mathrm{T}$ cell activation. $\mathrm{J}$ Exp Med 2007; 204(12): 2977-87.

[50] Martin AL, Schwartz MD, Jameson SC, Shimizu Y. Selective regulation of CD8 effector T cell migration by the p110 gamma isoform of phosphatidylinositol 3-kinase. J Immunol 2008; 180(4): 2081-8.

[51] Tassi I, Cella M, Gilfillan S, et al. p110gamma and p110delta phosphoinositide 3-kinase signaling pathways synergize to control development and functions of murine NK cells. Immunity 2007; 27(2): 214-27.

[52] Guo H, Samarakoon A, Vanhaesebroeck B, Malarkannan S. The p110 delta of PI3K plays a critical role in NK cell terminal maturation and cytokine/chemokine generation. J Exp Med 2008; 205(10): 2419-35.

[53] Kim N, Saudemont A, Webb L, et al. The p110delta catalytic isoform of PI3K is a key player in NK-cell development and cytokine secretion. Blood 2007; 110(9): 3202-8.

[54] Ferguson GJ, Milne L, Kulkarni S, et al. PI(3)Kgamma has an important context-dependent role in neutrophil chemokinesis. Nat Cell Biol 2007; 9(1): 86-91.

[55] Nishio M, Watanabe K, Sasaki J, et al. Control of cell polarity and motility by the PtdIns $(3,4,5) \mathrm{P} 3$ phosphatase SHIP1. Nat Cell Biol 2007; 9(1): 36-44.

[56] Condliffe AM, Davidson K, Anderson KE, et al. Sequential activation of class IB and class IA PI3K is important for the primed respiratory burst of human but not murine neutrophils. Blood 2005; 106(4): 1432-40.

[57] Liu L, Puri KD, Penninger JM, Kubes P. Leukocyte PI3Kgamma and PI3Kdelta have temporally distinct roles for leukocyte recruitment in vivo. Blood 2007; 110(4): 1191-8.

[58] Laffargue M, Calvez R, Finan P, et al. Phosphoinositide 3-kinase gamma is an essential amplifier of mast cell function. Immunity 2002; 16(3): 441-51.

[59] Del Prete A, Vermi W, Dander E, et al. Defective dendritic cell migration and activation of adaptive immunity in PI3Kgammadeficient mice. EMBO J 2004; 23(17): 3505-15.

[60] Costa C, Barberis L, Ambrogio C, et al. Negative feedback regulation of $\mathrm{Rac}$ in leukocytes from mice expressing a constitutively active phosphatidylinositol 3-kinase gamma. Proc Natl Acad Sci USA 2007; 104(36): 14354-9.

[61] Llorian M, Stamataki Z, Hill S, Turner M, Martensson IL. The PI3K p110delta is required for down-regulation of RAG expression in immature B cells. J Immunol 2007; 178(4): 1981-5.

[62] Janas ML, Hodson D, Stamataki Z, et al. The effect of deleting p110delta on the phenotype and function of PTEN-deficient B cells. J Immunol 2008; 180(2): 739-46.

[63] Henley T, Kovesdi D, Turner M. B-cell responses to B-cell activation factor of the TNF family (BAFF) are impaired in the absence of PI3K delta. Eur J Immunol 2008; 38(12): 3543-8.

[64] Rolf J, Bell SE, Kovesdi D, et al. Phosphoinositide 3-kinase activity in $\mathrm{T}$ cells regulates the magnitude of the germinal center reaction. J Immunol 2010; 185(7): 4042-52.

[65] Zebedin E, Simma O, Schuster C, et al. Leukemic challenge unmasks a requirement for PI3Kdelta in NK cell-mediated tumor surveillance. Blood 2008; 112(12): 4655-64. 
[66] Sadhu C, Masinovsky B, Dick K, Sowell CG, Staunton DE. Essential role of phosphoinositide 3-kinase delta in neutrophil directional movement. J Immunol 2003; 170(5): 2647-54.

[67] Bilancio A, Okkenhaug K, Camps M, et al. Key role of the p110delta isoform of PI3K in B-cell antigen and IL-4 receptor signaling: comparative analysis of genetic and pharmacologic interference with p110delta function in B cells. Blood 2006; 107(2): 642-50.

[68] Zhang TT, Okkenhaug K, Nashed BF, et al. Genetic or pharmaceutical blockade of p110delta phosphoinositide 3-kinase enhances IgE production. J Allergy Clin Immunol 2008; 122(4): 811-9 e2.

[69] Omori SA, Cato MH, Anzelon-Mills A, et al. Regulation of classswitch recombination and plasma cell differentiation by phosphatidylinositol 3-kinase signaling. Immunity 2006; 25(4): 545-57.

[70] Pinho V, Russo RC, Amaral FA, et al. Tissue- and stimulusdependent role of phosphatidylinositol 3-kinase isoforms for neutrophil recruitment induced by chemoattractants in vivo. J Immunol 2007; 179(11): 7891-8.

[71] Soond DR, Bjorgo E, Moltu K, et al. PI3K p110delta regulates Tcell cytokine production during primary and secondary immune responses in mice and humans. Blood 2010; 115(11): 2203-13.

[72] Macintyre AN, Finlay D, Preston G, et al. Protein kinase B controls transcriptional programs that direct cytotoxic $\mathrm{T}$ cell fate but is dispensable for T cell metabolism. Immunity 2011; 34(2): 224-36.

[73] Waugh C, Sinclair L, Finlay D, Bayascas JR, Cantrell D. Phosphoinositide $(3,4,5)$-triphosphate binding to phosphoinositidedependent kinase 1 regulates a protein kinase B/Akt signaling threshold that dictates T-cell migration, not proliferation. Mol Cell Biol 2009; 29(21): 5952-62.

[74] Durand CA, Hartvigsen K, Fogelstrand L, et al. Phosphoinositide 3-kinase p1 10 delta regulates natural antibody production, marginal zone and B-1 B cell function, and autoantibody responses. J Immunol 2009; 183(9): 5673-84.

[75] Ramadani F, Bolland DJ, Garcon F, et al. The PI3K isoforms p110alpha and p110delta are essential for pre-B cell receptor signaling and B cell development. Sci Signal 2010; 3(134): ra60.

[76] Okkenhaug K, Patton DT, Bilancio A, Garcon F, Rowan WC, Vanhaesebroeck B. The p110delta isoform of phosphoinositide 3kinase controls clonal expansion and differentiation of Th cells. J Immunol 2006; 177(8): 5122-8.

[77] Jarmin SJ, David R, Ma L, et al. $\mathrm{T}$ cell receptor-induced phosphoinositide-3-kinase p110delta activity is required for $\mathrm{T}$ cell localization to antigenic tissue in mice. J Clin Invest 2008; 118(3): 1154-64.

[78] Nashed BF, Zhang T, Al-Alwan M, et al. Role of the phosphoinositide 3-kinase p110delta in generation of type 2 cytokine responses and allergic airway inflammation. Eur J Immunol 2007; 37(2): 416-24.

[79] Patton DT, Garden OA, Pearce WP, et al. Cutting edge: the phosphoinositide 3-kinase p1 10 delta is critical for the function of CD4+CD25+Foxp3+ regulatory T cells. J Immunol 2006; 177(10): 6598-602.

[80] Sinclair LV, Finlay D, Feijoo C, et al. Phosphatidylinositol-3-OH kinase and nutrient-sensing mTOR pathways control T lymphocyte trafficking. Nat Immunol 2008; 9(5): 513-21.

[81] Liu D, Zhang T, Marshall AJ, Okkenhaug K, Vanhaesebroeck B, Uzonna JE. The p110delta isoform of phosphatidylinositol 3-kinase controls susceptibility to Leishmania major by regulating expansion and tissue homing of regulatory $\mathrm{T}$ cells. J Immunol 2009; 183(3): 1921-33.

[82] Ali K, Bilancio A, Thomas M, et al. Essential role for the p110delta phosphoinositide 3-kinase in the allergic response. Nature 2004; 431(7011): 1007-11.

[83] Ali K, Camps M, Pearce WP, et al. Isoform-specific functions of phosphoinositide 3-kinases: p110 delta but not p110 gamma promotes optimal allergic responses in vivo. J Immunol 2008; 180(4): 2538-44.

[84] Krishnamoorthy N, Oriss TB, Paglia M, et al. Activation of c-Kit in dendritic cells regulates $\mathrm{T}$ helper cell differentiation and allergic asthma. Nat Med 2008; 14(5): 565-73.

[85] Ji H, Rintelen F, Waltzinger C, et al. Inactivation of PI3Kgamma and PI3Kdelta distorts T-cell development and causes multiple organ inflammation. Blood 2007; 110(8): 2940-7.
[86] Webb LM, Vigorito E, Wymann MP, Hirsch E, Turner M. Cutting edge: $\mathrm{T}$ cell development requires the combined activities of the p110gamma and p110delta catalytic isoforms of phosphatidylinositol 3-kinase. J Immunol 2005; 175(5): 2783-7.

[87] Swat W, Montgrain V, Doggett TA, et al. Essential role of PI3Kdelta and PI3Kgamma in thymocyte survival. Blood 2006; 107(6): 2415-22.

[88] Janas ML, Varano G, Gudmundsson K, Noda M, Nagasawa T, Turner M. Thymic development beyond beta-selection requires phosphatidylinositol 3-kinase activation by CXCR4. J Exp Med 2010; 207(1): 247-61.

[89] Beer-Hammer S, Zebedin E, von Holleben M, et al. The catalytic PI3K isoforms p110gamma and p110delta contribute to B cell development and maintenance, transformation, and proliferation. J Leukoc Biol 2010; 87(6): 1083-95.

[90] Fung-Leung WP. Phosphoinositide 3-kinase delta (PI3Kdelta) in leukocyte signaling and function. Cell Signal 2011; 23(4): 603-8.

[91] Ghigo A, Damilano F, Braccini L, Hirsch E. PI3K inhibition in inflammation: toward tailored therapies for specific diseases. Bioessays 2010; 32(3): 185-96.

[92] Okkenhaug K, Fruman DA. PI3Ks in lymphocyte signaling and development. Curr Top Microbiol Immunol 2010; 346: 57-85.

[93] Fruman DA, Snapper SB, Yballe CM, et al. Impaired B cell development and proliferation in absence of phosphoinositide 3kinase p85alpha. Science 1999; 283(5400): 393-7.

[94] Suzuki H, Terauchi Y, Fujiwara M, et al. Xid-like immunodeficiency in mice with disruption of the p85alpha subunit of phosphoinositide 3-kinase. Science 1999; 283(5400): 390-2.

[95] Dil N, Marshall AJ. Role of phosphoinositide 3-kinase p110 delta in TLR4- and TLR9-mediated B cell cytokine production and differentiation. Mol Immunol 2009; 46(10): 1970-8.

[96] Suzuki A, Kaisho T, Ohishi M, et al. Critical roles of Pten in B cell homeostasis and immunoglobulin class switch recombination. J Exp Med 2003; 197(5): 657-67.

[97] Iwata Y, Matsushita T, Horikawa M, et al. Characterization of a rare IL-10-competent B-cell subset in humans that parallels mouse regulatory B10 cells. Blood. 2011; 117(2): 530-41.

[98] DiLillo DJ, Matsushita T, Tedder TF. B10 cells and regulatory B cells balance immune responses during inflammation, autoimmunity, and cancer. Ann N Y Acad Sci 2010; 1183: 38-57.

[99] Blair PA, Norena LY, Flores-Borja F, et al. CD19(+)CD24(hi)CD 38(hi) B cells exhibit regulatory capacity in healthy individuals but are functionally impaired in systemic Lupus Erythematosus patients. Immunity 2010; 32(1): 129-40.

[100] Hoellenriegel J, Meadows SA, Wierda WG, Keating MJ, Lannutti B, Burger JA. Phosphoinositide 3'-Kinase (PI3K) Delta Inhibition with CAL-101 Blocks B-Cell Receptor (BCR) Signaling and the Prosurvival Actions of Nurslike Cells (NLC), In Chronic Lymphocytic Leukemia. ASH Annu Meet Abst 2010; 116(21): 48.

[101] Hoellenriegel J, Meadows SA, Sivina M, et al. The phosphoinositide 3'-kinase delta inhibitor, CAL-101, inhibits B-cell receptor signaling and chemokine networks in chronic lymphocytic leukemia. Blood 2011; 118(13): 3603-12.

[102] Haylock-Jacobs S, Comerford I, Bunting M, et al. PI3Kdelta drives the pathogenesis of experimental autoimmune encephalomyelitis by inhibiting effector $\mathrm{T}$ cell apoptosis and promoting Th17 differentiation. J Autoimmun 2011; 36(3-4): 278-87.

[103] Rolf J, Fairfax K, Turner M. Signaling pathways in T follicular helper cells. J Immunol 2010; 184(12): 6563-8.

[104] Dong W, Zhu P, Wang Y, Wang Z. Follicular helper T cells in systemic lupus erythematosus: a potential therapeutic target. Autoimmun Rev 2011; 10(6): 299-304.

[105] Hoyer BF, Moser K, Hauser AE, et al. Short-lived plasmablasts and long-lived plasma cells contribute to chronic humoral autoimmunity in NZB/W mice. J Exp Med 2004; 199(11): 157784.

[106] Gigoux M, Shang J, Pak Y, et al. Inducible costimulator promotes helper T-cell differentiation through phosphoinositide 3-kinase. Proc Natl Acad Sci USA 2009; 106(48): 20371-6.

[107] Sakaguchi S, Yamaguchi T, Nomura T, Ono M. Regulatory T cells and immune tolerance. Cell 2008; 133(5): 775-87.

[108] Patton DT, Wilson MD, Rowan WC, Soond DR, Okkenhaug K. The PI3K p110delta regulates expression of CD38 on regulatory $\mathrm{T}$ cells. PLoS One 2011; 6(3): e17359. 
[109] Delgoffe GM, Kole TP, Zheng Y, et al. The mTOR kinase differentially regulates effector and regulatory $\mathrm{T}$ cell lineage commitment. Immunity 2009; 30(6): 832-44.

[110] Delgoffe GM, Pollizzi KN, Waickman AT, et al. The kinase mTOR regulates the differentiation of helper $\mathrm{T}$ cells through the selective activation of signaling by mTORC1 and mTORC2. Nat Immunol 2011; 12(4): 295-303.

[111] Battaglia M, Stabilini A, Roncarolo MG. Rapamycin selectively expands CD4+CD25+FoxP3+ regulatory T cells. Blood 2005; 105(12): 4743-8.

[112] Berndt A, Miller S, Williams O, et al. The p110 delta structure: mechanisms for selectivity and potency of new PI(3)K inhibitors. Nat Chem Biol. 2010; 6(2): 117-24.

[113] Nauseef WM. How human neutrophils kill and degrade microbes: an integrated view. Immunol Rev 2007; 219: 88-102.

[114] Hawkins PT, Stephens LR, Suire S, Wilson M. PI3K signaling in neutrophils. Curr Top Microbiol Immunol 2010; 346: 183-202.

[115] Puri KD, Doggett TA, Huang CY, et al. The role of endothelial PI3Kgamma activity in neutrophil trafficking. Blood 2005; 106(1): 150-7.

[116] Ellson C, Davidson K, Anderson K, Stephens LR, Hawkins PT. PtdIns3P binding to the PX domain of p40phox is a physiological signal in NADPH oxidase activation. EMBO J 2006; 25(19): 446878.

[117] Berger SB, Romero X, Ma C, et al. SLAM is a microbial sensor that regulates bacterial phagosome functions in macrophages. Nat Immunol 2010; 11(10): 920-7.

[118] Barberis L, Pasquali C, Bertschy-Meier D, et al. Leukocyte transmigration is modulated by chemokine-mediated PI3Kgammadependent phosphorylation of vimentin. Eur J Immunol 2009; 39(4): 1136-46.

[119] Randis TM, Puri KD, Zhou H, Diacovo TG. Role of PI3Kdelta and PI3Kgamma in inflammatory arthritis and tissue localization of neutrophils. Eur J Immunol 2008; 38(5): 1215-24.

[120] Puri KD, Doggett TA, Douangpanya J, et al. Mechanisms and implications of phosphoinositide 3-kinase delta in promoting neutrophil trafficking into inflamed tissue. Blood 2004; 103(9): 3448-56.

[121] Maus UA, Backi M, Winter $\mathrm{C}$, et al. Importance of phosphoinositide 3-kinase gamma in the host defense against pneumococcal infection. Am J Respir Crit Care Med 2007; 175(9): 958-66.

[122] Berod L, Heinemann C, Heink S, et al. PI3Kgamma deficiency delays the onset of experimental autoimmune encephalomyelitis and ameliorates its clinical outcome. Eur J Immunol 2011; 41(3): 833-44.

[123] Konrad S, Ali SR, Wiege K, et al. Phosphoinositide 3-kinases gamma and delta, linkers of coordinate C5a receptor-Fcgamma receptor activation and immune complex-induced inflammation. J Biol Chem 2008; 283(48): 33296-303.

[124] Palframan RT, Collins PD, Severs NJ, Rothery S, Williams TJ, Rankin SM. Mechanisms of acute eosinophil mobilization from the bone marrow stimulated by interleukin 5: the role of specific adhesion molecules and phosphatidylinositol 3-kinase. J Exp Med 1998; 188(9): 1621-32.

[125] Ezeamuzie CI, Sukumaran J, Philips E. Effect of wortmannin on human eosinophil responses in vitro and on bronchial inflammation and airway hyperresponsiveness in Guinea pigs in vivo. Am J Respir Crit Care Med 2001; 164(9): 1633-9.

[126] Lim DH, Cho JY, Song DJ, Lee SY, Miller M, Broide DH. PI3K gamma-deficient mice have reduced levels of allergen-induced eosinophilic inflammation and airway remodeling. Am J Physiol Lung Cell Mol Physiol 2009; 296(2): L210-9.

[127] Takeda M, Ito W, Tanabe M, et al. Allergic airway hyperresponsiveness, inflammation, and remodeling do not develop in phosphoinositide 3-kinase gamma-deficient mice. J Allergy Clin Immunol 2009; 123(4): 805-12.

[128] Scott DL, Wolfe F, Huizinga TW. Rheumatoid arthritis. Lancet 2010; 376(9746): 1094-108.

[129] Donahue KE, Gartlehner G, Jonas DE, et al. Systematic review: comparative effectiveness and harms of disease-modifying medications for rheumatoid arthritis. Ann Intern Med 2008; 148(2): 124-34.

[130] Suarez-Almazor ME, Belseck E, Shea B, Wells G, Tugwell P. Methotrexate for rheumatoid arthritis. Cochrane Database Syst Rev 2000(2): CD000957.
[131] Osiri M, Shea B, Robinson V, et al. Leflunomide for treating rheumatoid arthritis. Cochrane Database Syst Rev 2003; 1: CD002047.

[132] Suarez-Almazor ME, Belseck E, Shea B, Wells G, Tugwell P. Sulfasalazine for rheumatoid arthritis. Cochrane Database Syst Rev 2000(2): CD000958.

[133] Elliott MJ, Maini RN, Feldmann M, K et al. Randomised doubleblind comparison of chimeric monoclonal antibody to tumour necrosis factor alpha (cA2) versus placebo in rheumatoid arthritis. Lancet 1994; 344(8930): 1105-10.

[134] Genant HK, Peterfy CG, Westhovens R, et al. Abatacept inhibits progression of structural damage in rheumatoid arthritis: results from the long-term extension of the AIM trial. Ann Rheum Dis 2008; 67(8): 1084-9.

[135] Cohen SB, Emery P, Greenwald MW, et al. Rituximab for rheumatoid arthritis refractory to anti-tumor necrosis factor therapy: Results of a multicenter, randomized, double-blind, placebo-controlled, phase III trial evaluating primary efficacy and safety at twenty-four weeks. Arthritis Rheum 2006; 54(9): 2793806.

[136] Maini RN, Taylor PC, Szechinski J, et al. Double-blind randomized controlled clinical trial of the interleukin-6 receptor antagonist, tocilizumab, in European patients with rheumatoid arthritis who had an incomplete response to methotrexate. Arthritis Rheum 2006; 54(9): 2817-29.

[137] Singh JA, Wells GA, Christensen R, et al. Adverse effects of biologics: a network meta-analysis and Cochrane overview. Cochrane Database Syst Rev 2011(2): CD008794.

[138] Firestein GS. The T cell cometh: interplay between adaptive immunity and cytokine networks in rheumatoid arthritis. J Clin Invest 2004; 114(4): 471-4.

[139] Benoist C, Mathis D. A revival of the B cell paradigm for rheumatoid arthritis pathogenesis? Arthritis Res 2000; 2(2): 90-4.

[140] Sarkar S, Fox DA. Dendritic cells in rheumatoid arthritis. Front Biosci 2005; 10: 656-65.

[141] Benoist C, Mathis D. Mast cells in autoimmune disease. Nature 2002; 420(6917): 875-8.

[142] Wipke BT, Allen PM. Essential role of neutrophils in the initiation and progression of a murine model of rheumatoid arthritis. J Immunol 2001; 167(3): 1601-8.

[143] Choi Y, Arron JR, Townsend MJ. Promising bone-related therapeutic targets for rheumatoid arthritis. Nat Rev Rheumatol 2009; 5(10): 543-8.

[144] Camps M, Ruckle T, Ji H, et al. Blockade of PI3Kgamma suppresses joint inflammation and damage in mouse models of rheumatoid arthritis. Nat Med 2005; 11(9): 936-43.

[145] Hayer S, Pundt N, Peters MA, et al. PI3Kgamma regulates cartilage damage in chronic inflammatory arthritis. FASEB J 2009; 23(12): 4288-98.

[146] Toyama S, Tamura N, Haruta K, et al. Inhibitory effects of ZSTK474, a novel phosphoinositide 3-kinase inhibitor, on osteoclasts and collagen-induced arthritis in mice. Arthritis Res Ther 2010; 12(3): R92.

[147] Marwick JA, Caramori G, Stevenson CS, et al. Inhibition of PI3Kdelta restores glucocorticoid function in smoking-induced airway inflammation in mice. Am J Respir Crit Care Med 2009; 179(7): 542-8.

[148] Thurlings RM, Wijbrandts CA, Bennink RJ, et al. Monocyte scintigraphy in rheumatoid arthritis: the dynamics of monocyte migration in immune-mediated inflammatory disease. PLoS One 2009; 4(11): e7865.

[149] Kollias G, Papadaki P, Apparailly F, et al. Animal models for arthritis: innovative tools for prevention and treatment. Ann Rheum Dis 2011; 70(8): 1357-62.

[150] Bevaart L, Vervoordeldonk MJ, Tak PP. Evaluation of therapeutic targets in animal models of arthritis: how does it relate to rheumatoid arthritis? Arthritis Rheum 2010; 62(8): 2192-205.

[151] Kim G, Jun JB, Elkon KB. Necessary role of phosphatidylinositol 3-kinase in transforming growth factor beta-mediated activation of Akt in normal and rheumatoid arthritis synovial fibroblasts. Arthritis Rheum 2002; 46(6): 1504-11.

[152] Brennan FM, Hayes AL, Ciesielski CJ, Green P, Foxwell BM, Feldmann M. Evidence that rheumatoid arthritis synovial $\mathrm{T}$ cells are similar to cytokine-activated $\mathrm{T}$ cells: involvement of phosphatidylinositol 3-kinase and nuclear factor kappaB pathways 
in tumor necrosis factor alpha production in rheumatoid arthritis. Arthritis Rheum 2002; 46(1): 31-41.

[153] Pap T, Franz JK, Hummel KM, Jeisy E, Gay R, Gay S. Activation of synovial fibroblasts in rheumatoid arthritis: lack of Expression of the tumour suppressor PTEN at sites of invasive growth and destruction. Arthritis Res 2000; 2(1): 59-64

[154] Liu H, Huang Q, Shi B, Eksarko P, Temkin V, Pope RM. Regulation of Mcl-1 expression in rheumatoid arthritis synovial macrophages. Arthritis Rheum 2006; 54(10): 3174-81.

[155] Foey A, Green P, Foxwell B, Feldmann M, Brennan F. Cytokinestimulated $\mathrm{T}$ cells induce macrophage IL-10 production dependent on phosphatidylinositol 3-kinase and p70S6K: implications for rheumatoid arthritis. Arthritis Res 2002; 4(1): 64-70.

[156] Williams O, Houseman BT, Kunkel EJ, et al. Discovery of dual inhibitors of the immune cell PI3Ks p110delta and p110gamma: a prototype for new anti-inflammatory drugs. Chem Biol 2010; 17(2): 123-34

[157] Abu-Shakra M, Urowitz MB, Gladman DD, Gough J. Mortality studies in systemic lupus erythematosus. Results from a single center. II. Predictor variables for mortality. J Rheumatol 1995; 22(7): 1265-70

[158] Rahman A, Isenberg DA. Systemic lupus erythematosus. New Engl J Med 2008; 358(9): 929-39.

[159] Craft JE. Dissecting the immune cell mayhem that drives lupus pathogenesis. Sci Transl Med 2011; 3(73): 73ps9.

[160] Navarra SV, Guzman RM, Gallacher AE, et al. Efficacy and safety of belimumab in patients with active systemic lupus erythematosus: a randomised, placebo-controlled, phase 3 trial. Lancet 2011; 377(9767): 721-31.

[161] Hahn BH. Targeted therapies in systemic lupus erythematosus: successes, failures and future. Ann Rheum Dis 2011; 70 (Suppl 1): i64-i6.

[162] Wallace DJ, Stohl W, Furie RA, et al. A phase II, randomized, double-blind, placebo-controlled, dose-ranging study of belimumab in patients with active systemic lupus erythematosus. Arthritis Rheum 2009; 61(9): 1168-78.

[163] Patke A, Mecklenbrauker I, Erdjument-Bromage H, Tempst P, Tarakhovsky A. BAFF controls B cell metabolic fitness through a PKC beta- and Akt-dependent mechanism. J Exp Med 2006; 203(11): 2551-62.

[164] Otipoby KL, Sasaki Y, Schmidt-Supprian M, et al. BAFF activates Akt and Erk through BAFF-R in an IKK1-dependent manner in primary mouse B cells. Proc Natl Acad Sci USA 2008; 105(34): 12435-8.

[165] Borlado LR, Redondo C, Alvarez B, et al. Increased phosphoinositide 3-kinase activity induces a lymphoproliferative disorder and contributes to tumor generation in vivo. FASEB J 2000; 14(7): 895-903.

[166] Parsons MJ, Jones RG, Tsao MS, Odermatt B, Ohashi PS, Woodgett JR. Expression of active protein kinase B in T cells perturbs both $\mathrm{T}$ and $\mathrm{B}$ cell homeostasis and promotes inflammation. J Immunol 2001; 167(1): 42-8.

[167] Cantley LC, Neel BG. New insights into tumor suppression: PTEN suppresses tumor formation by restraining the phosphoinositide 3kinase/AKT pathway. Proc Natl Acad Sci USA 1999; 96(8): 42405 .

[168] Barber DF, Bartolome A, Hernandez C, et al. PI3Kgamma inhibition blocks glomerulonephritis and extends lifespan in a mouse model of systemic lupus. Nat Med 2005; 11(9): 933-5.

[169] Barber DF, Bartolome A, Hernandez C, et al. Class IBphosphatidylinositol 3-kinase (PI3K) deficiency ameliorates IA-
PI3K-induced systemic lupus but not $\mathrm{T}$ cell invasion. J Immunol 2006; 176(1): 589-93.

[170] Vinuesa CG, Cook MC, Angelucci C, et al. A RING-type ubiquitin ligase family member required to repress follicular helper $\mathrm{T}$ cells and autoimmunity. Nature 2005; 435(7041): 452-8.

[171] $\mathrm{Yu} \mathrm{D}$, Tan $\mathrm{AH}, \mathrm{Hu} \mathrm{X}$, et al. Roquin represses autoimmunity by limiting inducible T-cell co-stimulator messenger RNA. Nature 2007; 450(7167): 299-303.

[172] Simpson N, Gatenby PA, Wilson A, et al. Expansion of circulating $\mathrm{T}$ cells resembling follicular helper $\mathrm{T}$ cells is a fixed phenotype that identifies a subset of severe systemic lupus erythematosus. Arthritis Rheum 2010; 62(1): 234-44.

[173] Suarez-Fueyo A, Barber DF, Martinez-Ara J, Zea-Mendoza AC, Carrera AC. Enhanced phosphoinositide 3-kinase delta activity is a frequent event in systemic lupus erythematosus that confers resistance to activation-induced $\mathrm{T}$ cell death. J Immunol 2011; 187(5): 2376-85

[174] Li J, Fu Q, Cui H, et al. Interferon-alpha priming promotes lipid uptake and macrophage-derived foam cell formation: a novel link between interferon-alpha and atherosclerosis in lupus. Arthritis Rheum 2011; 63(2): 492-502.

[175] Lee KS, Lee HK, Hayflick JS, Lee YC, Puri KD. Inhibition of phosphoinositide 3-kinase delta attenuates allergic airway inflammation and hyperresponsiveness in murine asthma model. FASEB J 2006; 20(3): 455-65.

[176] Marwick JA, Caramori G, Casolari P, et al. A role for phosphoinositol 3-kinase delta in the impairment of glucocorticoid responsiveness in patients with chronic obstructive pulmonary disease. J Allergy Clin Immunol 2010; 125(5): 1146-53.

[177] Park SJ, Lee KS, Kim SR, et al. Phosphoinositide 3-kinase delta inhibitor suppresses interleukin-17 expression in a murine asthma model. Eur Respir J 2010; 36(6): 1448-59.

[178] Lee KS, Park SJ, Kim SR, et al. Phosphoinositide 3-kinase-delta inhibitor reduces vascular permeability in a murine model of asthma. J Allergy Clin Immunol 2006; 118(2): 403-9.

[179] Thomas MJ, Smith A, Head DH, et al. Airway inflammation: chemokine-induced neutrophilia and the class I phosphoinositide 3kinases. Eur J Immunol 2005; 35(4): 1283-91.

[180] Doukas J, Eide L, Stebbins K, et al. Aerosolized phosphoinositide 3-kinase gamma/delta inhibitor TG100-115 [3- [2,4-diamino-6-(3hydroxyphenyl)pteridin-7-yl]phenol] as a therapeutic candidate for asthma and chronic obstructive pulmonary disease. J Pharmacol Exp Ther 2009; 328(3): 758-65.

[181] Fougerat A, Gayral S, Gourdy P, et al. Genetic and pharmacological targeting of phosphoinositide 3-kinase-gamma reduces atherosclerosis and favors plaque stability by modulating inflammatory processes. Circulation 2008; 117(10): 1310-7.

[182] Norman P. Selective PI3Kdelta inhibitors, a review of the patent literature. Expert Opin Ther Pat 2011; 21(11): 1773-90.

[183] Ruckle T, Schwarz MK, Rommel C. PI3Kgamma inhibition: towards an 'aspirin of the 21st century'? Nat Rev Drug Discov 2006; 5(11): 903-18

[184] Bartok B, Boyle DL, Liu Y, et al. PI3 kinase delta is a key regulator of synoviocyte function in rheumatoid arthritis. Am Pathol 2012; 180(5): 1906-16.

[185] Maxwell MJ, Tsantikos E, Kong AM, Vanhaesebroeck B, Tarlinton DM, Hibbs ML. Attenuation of phosphoinositide 3-kinase delta signaling restrains autoimmune disease. J Autoimmun 2012; 38(4): $381-91$ 